\title{
RBPJ $\kappa$-Dependent Signaling Is Essential for Long-Term Maintenance of Neural Stem Cells in the Adult Hippocampus
}

\author{
Oliver Ehm, ${ }^{1}$ Christian Göritz, ${ }^{4}$ Marcela Covic, ${ }^{1}$ Iris Schäffner, ${ }^{1}$ Tobias J. Schwarz, ${ }^{1}$ Esra Karaca, ${ }^{1}$ Bettina Kempkes, ${ }^{2}$ \\ Elisabeth Kremmer, ${ }^{3}$ Frank W. Pfrieger, ${ }^{5}$ Lluis Espinosa, ${ }^{6}$ Anna Bigas, ${ }^{6}$ Claudio Giachino, ${ }^{7}$ Verdon Taylor, ${ }^{7}$ \\ Jonas Frisén, ${ }^{4}$ and D. Chichung Lie ${ }^{1}$ \\ ${ }^{1}$ Research Group Adult Neurogenesis and Neural Stem Cells, Institute of Developmental Genetics, ${ }^{2}$ Department of Gene Vectors, and ${ }^{3}$ Institute of Molecular \\ Immunology, Helmholtz Zentrum München, German Research Center for Environmental Health, 85764 Munich-Neuherberg, Germany, ${ }^{4}$ Department of \\ Cell and Molecular Biology, Medical Nobel Institute, Karolinska Institute, SE-171 77 Stockholm, Sweden, ${ }^{5}$ Centre National de la Recherche Scientifique \\ Unité Propre de Recherche-3212, Institute of Cellular and Integrative Neurosciences, University of Strasbourg, 67084 Strasbourg, France, ${ }^{6}$ Institut \\ Municipal d'Investigació Mèdica-Hospital del Mar, Parc de Recerca Biomèdica de Barcelona, 08003 Barcelona, Spain, and Department of Molecular \\ Embryology, Max Planck Institute of Immunobiology, 79108 Freiburg, Germany
}

The generation of new neurons from neural stem cells in the adult hippocampal dentate gyrus contributes to learning and mood regulation. To sustain hippocampal neurogenesis throughout life, maintenance of the neural stem cell pool has to be tightly controlled. We found that the Notch/RBPJ $\kappa$-signaling pathway is highly active in neural stem cells of the adult mouse hippocampus. Conditional inactivation of RBPJ $\kappa$ in neural stem cells in vivo resulted in increased neuronal differentiation of neural stem cells in the adult hippocampus at an early time point and depletion of the Sox2-positive neural stem cell pool and suppression of hippocampal neurogenesis at a later time point. Moreover, RBPJ $\kappa$-deficient neural stem cells displayed impaired self-renewal in vitro and loss of expression of the transcription factor Sox2. Interestingly, we found that Notch signaling increases Sox2 promoter activity and Sox2 expression in adult neural stem cells. In addition, activated Notch and RBPJ $\kappa$ were highly enriched on the Sox2 promoter in adult hippocampal neural stem cells, thus identifying Sox2 as a direct target of Notch/RBPJ $\kappa$ signaling. Finally, we found that overexpression of Sox 2 can rescue the self-renewal defect in RBPJ $\kappa$-deficient neural stem cells. These results identify RBPJ $\kappa$-dependent pathways as essential regulators of adult neural stem cell maintenance and suggest that the actions of RBPJ $\kappa$ are, at least in part, mediated by control of Sox 2 expression.

\section{Introduction}

In the adult mammalian brain, neural stem cells (NSCs) in the subgranular zone (SGZ) of the hippocampal dentate gyrus continuously give rise to new functional granule neurons. There is growing evidence that adult hippocampal neurogenesis is important for hippocampus-dependent learning (Kee et al., 2007; Imayoshi et al., 2008; Clelland et al., 2009; Deng et al., 2009; Jessberger et al., 2009) and that impaired neurogenesis may contribute to hippocampal dysfunction observed in neuropsychiatric diseases such as cognitive decline during aging (Kuhn et al., 1996; Drapeau et al., 2003), anxiety and depression (Bergami et

Received March 26, 2010; revised Aug. 17, 2010; accepted Aug. 19, 2010.

Work in the Lie laboratory was supported by the European Young Investigator Award from the European Science Foundation (DFG 858/6-2), the Marie Curie Excellence Team Program and the Marie Curie Reintegration Program of the European Union, the Bavarian Research Network on Adult Neural Stem Cells "FORNEUROCELL," the Helmholtz Alliance for Mental Health in an Ageing Society, the Bundesministerium für Bildung und Forschung Netzwerk "Cell Based Regenerative Medicine," and the European Commission Coordination Action ENINET (Network of European Neuroscience Institutes; contract LSHM-CT-2005-19063). We thank K. Wassmer, B. Eble-Müllerschön, M. Ram, and F. Gruhn for excellent technical support; W. Ehm for support of all statistical analyses; and members of the Lie laboratory for helpful discussion and suggestions. We are grateful to Drs. T. Michaelidis, S. Jessberger, L. Bally-Cuif, P. Chapouton, and F. H. Gage for discussion and comments on this manuscript. We also thank Dr. A. Eisch for sharing unpublished results.

Correspondence should be addressed to D. Chichung Lie, Adult Neurogenesis and Neural Stem Cell Group, Institute of Developmental Genetics, Helmholtz Zentrum München, German Research Center for Environmental Health, Ingolstaedter Landstrasse 1,85764 Munich-Neuherberg, Germany. E-mail: chichung.lie@helmholtz-muenchen.de. DOI:10.1523/JNEUROSCI.1567-10.2010

Copyright $\odot 2010$ the authors $\quad 0270-6474 / 10 / 3013794-14 \$ 15.00 / 0$ al., 2008; Revest et al., 2009), and epilepsy (Jessberger et al., 2005; Jakubs et al., 2006; Parent et al., 2006). The ability of NSCs to generate new neurons throughout life depends on the tight balance of stem cell maintenance and differentiation. Incomplete maintenance and premature differentiation will result in depletion of the NSC pool and, consequently, will lead to decreased levels of neurogenesis over time. Increased stem cell maintenance at the expense of neuronal differentiation will impair the ability of NSCs to generate neurons at a rate necessary for proper hippocampal function. Candidate pathways to control stem cell maintenance in the adult hippocampus include Notchdependent pathways, which are essential for NSC maintenance, proliferation, and survival during development (Ohtsuka et al., 1999; Hitoshi et al., 2002; Androutsellis-Theotokis et al., 2006; Basak and Taylor, 2007; Mizutani et al., 2007) and control stem cell maintenance in several stem cell niches of the adult organism (Yamamoto et al., 2003; Duncan et al., 2005; Blanpain et al., 2006; Song et al., 2007). Ablation of Notch1 in hippocampal NSCs during the early postnatal period and during adulthood promotes cell cycle exit and neuronal fate determination of NSCs, whereas forced Notch1 signaling increases proliferation of the NSC pool (Breunig et al., 2007). Whether Notch signaling is necessary to maintain the NSC pool and hippocampal neurogenesis throughout adulthood has not been determined. It is also unknown whether Notch signaling controls adult NSCs through the 
“canonical” (i.e., RBPJ $\kappa$-dependent) pathway. Here, we investigate the hypothesis that canonical Notch signaling controls NSC maintenance in the adult hippocampal neurogenic niche using conditional ablation of $\mathrm{RBPJ}_{\kappa}$ in adult hippocampal NSCs. We show that inactivation of RBPJ $\kappa$ leads to depletion of the NSC pool and long-term impairment of hippocampal neurogenesis. Moreover, we find evidence that disruption of RBPJ $\kappa$ affects hippocampal neurogenesis through cell-autonomous and cell non-autonomous mechanisms. Last, we identify the transcription factor Sox 2 as a novel Notch/RBPJ $\kappa$ downstream target that participates in the regulation of RBPJ $\kappa$ signaling-mediated adult NSC maintenance.

\section{Materials and Methods}

Animals. For all experiments, 8- to 12-week-old mice were used. Mice were group housed in standard cages under a $12 \mathrm{~h}$ light/dark cycle and had ad libitum access to food and water. C57BL/6 mice and $\mathrm{Tg}(\mathrm{Cp}$ EGFP)25Gaia were obtained from Charles River. Hes5-GFP reporter mice were described previously (Basak and Taylor, 2007). Four male $\mathrm{Tg}$ (Cp-EGFP)25Gaia and 3 Hes5-GFP reporter animals were analyzed.

GLAST::CreERT2 mice (Slezak et al., 2007) allow for expression of tamoxifen (TAM)-inducible Cre-recombinase controlled by promoter elements of the astrocyte-specific glutamate aspartate transporter (GLAST). GLAST::CreERT2 mice were crossed with RBPJ $\kappa^{\text {loxP/loxP }}$ mice, in which exons 6 and 7, which code for DNA- and Notch-binding domains, are flanked by loxP sites (Han et al., 2002) and with R26::EYFP reporter mice (Srinivas et al., 2001). TAM was injected daily ( $2 \mathrm{mg}$ ) for 5 consecutive days. For loss of RBPJ $\kappa$ function experiments, four to six animals per group were analyzed. Male and female transgenic mice were included in the analysis. Experimental groups were matched for age and sex.

Tissue processing. Animals were killed using $\mathrm{CO}_{2}$. Mice were perfused transcardially with PBS, $\mathrm{pH} 7.4$, for 5 min followed by $4 \%$ paraformaldehyde (PFA) for $5 \mathrm{~min}$. Brains were postfixed in 4\% PFA overnight at $4^{\circ} \mathrm{C}$ and were subsequently transferred to a $30 \%$ sucrose solution. Fortymicrometer-thick coronal brain sections were made using a sliding microtome (Leica).

Cell culture. Murine adult hippocampal stem/progenitor cells were kept under proliferating conditions in DMEM/F-12 (Invitrogen) supplemented with N2 supplement (Invitrogen), glutamine, and $1 \times$ penicillin/ streptomycin/fungizone (Invitrogen) in the presence of $20 \mathrm{ng} / \mathrm{ml} \mathrm{FGF2,}$ $20 \mathrm{ng} / \mathrm{ml}$ epidermal growth factor (EGF; PeproTech), and $0.5 \mu \mathrm{g} / \mathrm{ml}$ heparin (Sigma-Aldrich). Medium and growth factors were renewed every second day (Ray and Gage, 2006). Neurospheres were prepared as described previously (Haslinger et al., 2009).

Neurosphere assay. For expression of CRE-recombinase and Sox2, cDNAs for a CRE-recombinase carrying an additional nuclear localization signal (nls) (Kaspar et al., 2002) and murine Sox2 were cloned into the pCAG vector or the pCAG IRES-DSRED (Jagasia et al., 2009) to generate pCAGGFPnlsCRE (Tashiro et al., 2006) and pCAG-Sox2-DSRED.

For single-cell assay, neurospheres were dissociated to single cells and transduced with the retroviruses CAG-GFP, CAG-GFPnlsCRE, or CAGSox2-DSRED together with CAG-GFPnlsCRE retrovirus (multiplicity of infections, $\sim 1$ ). Two days after the transduction, $25 \mu \mathrm{l}$ of a suspension of 80 cells $/ \mathrm{ml}$ in culture medium supplemented with $20 \mathrm{ng} / \mathrm{ml} \mathrm{FGF2}$ and EGF were plated on two 60-well microtiter plates. Three hours after plating, wells containing transduced single cells were determined. Five days after plating, the percentage of single cells that had generated neurospheres was determined. Cells were supplied with $20 \mathrm{ng} / \mathrm{ml} \mathrm{FGF2} \mathrm{and}$ EGF every second day. Three independent experiments were conducted.

For assessment of primary and secondary neurosphere formation ability under low cell density conditions, $\mathrm{RBPJ} \kappa^{\mathrm{fl} / \mathrm{fl}}$ neurospheres were dissociated to single cells and transduced with the retroviruses CAG-GFP, CAG-GFPnlsCRE, or CAG-Sox2-DSRED together with CAG-GFPnlsCRE retrovirus (multiplicity of infections, $\sim 1$ ). Visual inspection of cells at $24 \mathrm{~h}$ after transduction revealed that virtually all cells were transduced with the respective retroviruses. One hundred twenty-five cells in $200 \mu \mathrm{l}$ of medium were seeded in a 96-well plate and cultured for $7 \mathrm{~d}$. The remaining cells were cultured at a density of 10 per microliter for $7 \mathrm{~d}$. Cells in 96-well plates were analyzed with a fluorescent microscope, and the number of primary neurospheres was determined. Bulk seeded neurospheres were passaged and seeded in a 96-well plate as described above. After $7 \mathrm{~d}$, the numbers of secondary neurospheres were determined. Three independent experiments were performed.

Retrovirus preparation. Retroviruses were generated as described previously. Virus-containing supernatant was harvested four times every $48 \mathrm{~h}$ after transfection and concentrated by two rounds of ultracentrifugation (Tashiro et al., 2006). Viral titers were about $1 \times 10^{8}$ colonyforming units $\mathrm{ml}^{-1}$.

Cell lines. DG75 Burkitt's lymphoma cell line (Ben-Bassat et al., 1977) and SM224.9 (Maier et al., 2005) were used in electrophoretic mobility shift assays (EMSAs). HEK293 cells were used in luciferase assays (Lengler et al., 2005).

Electroporation and luciferase assay. To generate the Sox2 luciferase reporter construct, $5.5 \mathrm{~kb}$ upstream of the Sox 2 transcription start site were cloned into the pGL3basic luciferase vector (Promega). Two million cells were used per electroporation. Cells were electroporated using a Nucleofector II electroporation device (Lonza Cologne). Medium including all supplements was changed $24 \mathrm{~h}$ after electroporation. Cells were analyzed $48 \mathrm{~h}$ after the electroporation using the dual luciferase kit (Promega) and a Centro LB 960 luminometer (Berthold Technologies). For manipulation of the Notch/RBPJ $\kappa$ pathway, we cloned the murine cDNA for the Notch intracellular domain (NICD) or for the dominantnegative RBPJ $\kappa$ mutant protein (Kato et al., 1997) into the pCAG IRES-GFP expression vector (Jagasia et al., 2009) to generate pCAG-NICD-IRESGFP or pCAG-RBPJ $\kappa$ R218H-IRES-GFP. Cells were electroporated with equal molar amounts $(500 \mathrm{fmol})$ of these vectors together with Sox2Luciferase $(3 \mu \mathrm{g})$ and Renilla-Luciferase (10 ng). HEK293 cells were transfected using $\mathrm{CaCl}_{2}$ and analyzed at multiple points in time between 6 and $48 \mathrm{~h}$ after transfection. Luciferase experiments were performed from three independent electroporations or transfections. For the time line, each point in time represents the mean of three independent experiments.

Histology and counting procedures. Sections were blocked in Trisbuffered saline (TBS) supplemented with 3\% normal donkey serum and $0.25 \%$ Triton X-100 for $60 \mathrm{~min}$. Brain sections were then incubated in blocking solution containing the primary antibodies at the appropriate dilutions at $4^{\circ} \mathrm{C}$ for $48 \mathrm{~h}$. Primary antibodies against the following antigens were used: $\beta$-galactosidase (rabbit, 1:2000; Cappel/MP Biomedicals), doublecortin (DCX; goat, 1:250; Santa Cruz Biotechnology), DCX (guinea pig, 1:1000; Millipore), GFAP (guinea pig, 1:1000; Zytomed Systems), GFAP (mouse, 1:500; Sigma-Aldrich), GFAP (rabbit, 1:500; Dako), green fluorescent protein (GFP; chicken, 1:1000; Aves Labs), NeuroD1 (goat, 1:200; Santa Cruz Biotechnology), NeuN clone A60 (mouse, 1:100; Millipore), proliferating cell nuclear antigen (PCNA; mouse, 1:500; Santa Cruz Biotechnology), Sox2 (goat, 1:1000; Santa Cruz Biotechnology), Sox2 (rabbit, 1:1000; Millipore), and 6-diamidino-2phenylindole (DAPI; 1:10,000; Sigma-Aldrich). After three washes in TBS, samples were incubated in blocking solution containing the secondary antibody coupled to Cy3, Cy5, FITC, or Alexa 488 (The Jackson Laboratory) at a dilution of 1:250 for $2 \mathrm{~h}$ at room temperature. Samples were washed three times with TBS, incubated in $10 \mathrm{mg} / \mathrm{ml}$ DAPI (SigmaAldrich) for $10 \mathrm{~min}$, and mounted in Aqua PolyMount (Polysciences).

Confocal single plane images and $Z$-stacks were taken on a FluoView 1000 (Olympus) or on a SP5 confocal microscope (Leica). The number of Sox2-, Sox2/GFAP-, DCX-, PCNA-, and yellow fluorescent protein (YFP)-expressing cells in the dentate gyrus was determined in every sixth $40 \mu \mathrm{m}$ section of the dorsal hippocampus. DAPI staining was used to trace the granule cell layer. For normalization, cell numbers were related to the analyzed granule cell layer volume. For phenotyping, all YFP+ cells were analyzed for coexpression with lineage-specific markers.

RNA isolation, cDNA production, and reverse transcription-PCR. Total RNA was isolated using the RNeasy kit (QIAGEN) or the Trizol reagent (Invitrogen). Isolated RNA was treated with DNase (Promega) according to the manufacturer's protocol. cDNA was synthesized using the Superscript First Strand Synthesis System for reverse transcription-PCR (RTPCR; Invitrogen). Quantitative real-time PCRs were performed on a StepOne device (Applied Biosystems Deutschland). Primers for RT-PCR were as follows: Notch1: forward, GCTGACCTGCGCATGTCTGCCATG; 
reverse, CATGTTGTCCTGGATGTTGGCATCTG; Notch2: forward, CACCTTGAAGCTGCAGACAT; reverse, TGGTAGACCAAGTCTGTGATGAT; Notch3: forward, ATATATATGGAGTTGCTCCCTTCC; reverse, GGCTTTGAGCAGACAAGACCCCTT; Notch4: forward, GGAAGCGACACGTACGAGTCTGG; reverse, CAACACCCGGCACATCGTAGGT; Dll1: forward, CCTCGTTCGAGACCTCAAGGGAG; reverse, TAGACGTGTGGGCAGTGCGTGC; Dll3: forward, CACGCCATTCCCAGACGAGTGC; reverse, GCAGTCGTCCAGGTCGTGCT; Jagged1: forward, CCTGCCAGTGCCTGAATGGACG; reverse, GGCTGTCACCAAGCAACAGACCC; Jagged2: forward, ACCGTGACCAAGTGCCTCAGGGCA; reverse, GAGCGGAGCCCACTGGTTGTTGG; RBPJ $к$ forward, TGGCACTGTTCAATCGCCTT; reverse, AATCTTGGGAGTGCCATGCCA; Hes1: forward, ACACCGGACAAACCAAAGAC; reverse, GTCACCTCGTTCATGCACTC; Hes5: forward, AGATGCTCAGTCCCAAGGAG; reverse, TAGCCCTCGCTGTAGTCCTG; Sox2: forward, GAGTGGAAACTTTTGTCCGAGA; reverse, GAAGCGTGTACTTATCCTTCTTCAT; GAPDH forward, GACCCCTTCATTGACCTCAAC; reverse, CTTCTCCATGGTGGTGAAGA.

Quantitative real-time PCR. Quantitative real-time PCRs were performed on a StepOne device (Applied Biosystems Deutschland). Power SYBR Green PCR Master Mix (Applied Biosystems) was used for detection. Primers for quantitative real-time PCR were as follows: Sox2 forward, GCGGAGTGGAAACTTTTGTCC; Sox2 reverse, CGGGAAGCGTGTACTTATCCT; RBPJ $\kappa$ forward, TTCTATGGCAACAGCGATG; RBPJ $\kappa$ reverse: TGTTGTGAACTGGCGTGGAAA.

Quantitative real-time PCR experiments were performed with cDNA from three independent biological replicates.

Western blotting. For nuclear cell extracts, cells were allowed to swell on ice in buffer A (in mm: 10 HEPES, pH 8, $10 \mathrm{KCl}, 0.1$ EDTA, 0.1 EGTA, 2 DTT) for $5 \mathrm{~min}$. Thirty microliters of IGEPAL (Sigma-Aldrich) were added, and the cells were vortexed for $10 \mathrm{~s}$. Cells were then centrifuged at $10,000 \mathrm{rpm}$ at $4^{\circ} \mathrm{C}$ for $1 \mathrm{~min}$. The supernatant constitutes the cytosolic cell fraction and was transferred into a new reaction tube. The pellet was resuspended in $180 \mu \mathrm{l}$ of buffer B (10 mM HEPES, pH 8, $10 \mathrm{~mm} \mathrm{KCl}, 0.1$ mм EDTA, 0.1 mм EGTA, 2 mм DTT, 400 mм NaCl, 1\% IGEPAL), incubated on a rotor shaker at $4^{\circ} \mathrm{C}$ for $15 \mathrm{~min}$, and centrifuged at 10,000 $\mathrm{rpm}$ at $4^{\circ} \mathrm{C}$ for $1 \mathrm{~min}$. The supernatant constitutes the nuclear cell fraction. When analyzed separately, $300 \mu \mathrm{l}$ of buffer A was added to the nuclear fraction to get an isotonic suspension $(\sim 150 \mathrm{~mm} \mathrm{NaCl})$.

Proteins were blotted on a $0.45 \mu \mathrm{m}$ BioTrace polyvinylidene difluoride-(polyvinylidenfluorid) membrane (Pall Corporation) and were blocked in 5\% milk solution [slim milk powder in TBS with $0.1 \%$ Triton X-100 (TBST) ]) for $1 \mathrm{~h}$ at room temperature. Primary antibodies were used in TBST with $3 \%$ BSA. Primary antibody incubation was performed under constant shaking/rolling overnight at $4^{\circ} \mathrm{C}$. Blots were washed three times with TBST. HRP-conjugated secondary antibodies were used at a dilution of 1:1000 in TBST. Secondary antibody incubation was performed under constant shaking/rolling for $1 \mathrm{~h}$ at room temperature. Blots were washed three times in TBST and one time in TBS. Protein bands were visualized using ECL solution (GE Healthcare) on ECL hyperfilms (GE Healthcare). The following primary antibodies were used: $\alpha$-tubulin (mouse, 1:1000; Sigma), Notch1 (rabbit, 1:1000; Santa Cruz Biotechnology), PARP (mouse, 1:2000; Santa Cruz Biotechnology), and Vimentin (mouse, 1:5000; Sigma). Three independent experiments were performed.

Preparation of nuclear protein cell extracts for EMSA. Adherent cells were washed with PBS, trypsinized, and spun down at $300 \times g$ for $15 \mathrm{~min}$ at room temperature. Suspension cultures were spun down, and the pellet was resuspended in PBS and centrifuged again. The pellet was resuspended in 3 vol of buffer A (in mM: 10 HEPES, pH 7.9, $10 \mathrm{KCl}, 1.5$ $\mathrm{MgCl}_{2}$ ) and incubated for $60 \mathrm{~min}$ on ice. Following homogenization, cells were centrifuged for $10 \mathrm{~s}$ at $14,000 \mathrm{rpm}$ at $4^{\circ} \mathrm{C}$. Three hundred microliters of buffer A were added to the pellet and briefly vortexed. The resulting suspension was centrifuged for $10 \mathrm{~s}$ at $14,000 \mathrm{rpm}$ at $4^{\circ} \mathrm{C}$. The pellet was resuspended in 3 vol of buffer B (20 mM HEPES, pH 7.9, 25\% glycerol, 4.2 M NaCl, 1.5 mм $\mathrm{MgCl}_{2}, 0.2$ mм EDTA, pH 8.5, 0.5 mм DTT, protease inhibitors), incubated for $30 \mathrm{~min}$ on ice, and centrifuged at $140,00 \mathrm{rpm}$ for $20 \mathrm{~min}$ at $4^{\circ} \mathrm{C}$. Aliquots were stored at $-80^{\circ} \mathrm{C}$.

EMSA. The MatInspector and Eldorado algorithms in Genomatix software (Genomatix Software) were used for the prediction of potential binding sites for RBPJ $\kappa$ in the promoter sequence of the Sox 2 gene. Predicted binding sites, with respect to the transcription start site, were as follows: \#1: from -4475 to -4461 , + strand: ATGCTGAGAAATTCC; \#2: from -3746 to -3732 , + strand: CTAATGAGAAATAG; \#3: from -2538 to -2524 , + strand: AGCCTGGGAGAATGG; \#4: from -1983 to -1969, - strand: GCTGTGGGAGAATGG; \#5: from -1472 to -1458 , + strand: AGGCTGGGAACAAGG.

Equimolar amounts of both single-stranded DNA oligonucleotides containing potential RBPJ $\kappa$-binding sites were mixed in annealing buffer. Oligonucleotides comprising RBPJ $\kappa$-binding sites were designed as follows: \#1 forward, CTAATTAGCAATGCTGAGAAATT; reverse, CCTTGTTAACTGGAATTTCTCAGC; \#2 forward, TGAGAAAATAGGTTTTGCTACCG; reverse, TATTTTCTCATTAGAA TATTTTT; \#3 forward, TGGGAGAATGGGGATTGGAGATG; reverse, ATTCTCC CAGGCTTGGCTGTTA; \#4 forward, CCCGCCCCCAGCCCATTCTCCCA; reverse, CAAGCCCAGGCTGTGGGAGAATGG; \#5 forward, AGGCTGGGAACAAGGCCTGGTCC; reverse, GTTCCCAGCCTTTTCCTAGGCCGA. In mutant constructs, the RBPJ $\kappa$-binding site TGGGA was mutated to TGCTG. Mutant constructs were designed as follows: \#1 forward, CTAATTAGCAATGCTGCTGCATT; reverse, CCTTGTTAACTGGAATGCAGCAGC; \#4 forward, CCCGCCCCCAGCCCATTGCAGCA; reverse, CAAGCCCAGGC TGTGCTGCAATGG; \#5 forward, AGGCTGCTGCCAAGGCCTGGTCC; reverse, GGCAGCAGCCTTTTCCTAGGCCGA. A total of $3000 \mathrm{Ci} / \mathrm{mol} \alpha-\mathrm{dCT}^{32} \mathrm{P}$ was used for radioactive labeling of the annealed oligonucleotides. Purification of radioactive oligonucleotides was performed on Sephadex G50 columns (Pharmacia/GE Healthcare Europe). A rat monoclonal antibody directed against RBPJ $\kappa$ (clone RBP1F1) was used. For supershift experiments, recombinant RBPJ $\kappa$ protein or nuclear extracts were used. For competition experiments, analogous amounts of nonradioactive-labeled oligonucleotides were used. The reaction was run at $130 \mathrm{~V}(6.5 \mathrm{~V} / \mathrm{cm})$ on a native $6 \%$ polyacrylamide gel for $3-4 \mathrm{~h}$.

Chromatin immunoprecipitations. Cross-linking was performed by adding $1 \mathrm{ml}$ of cross-linking solution [for $5 \times$ stock: $250 \mathrm{~mm}$ HEPES, $\mathrm{pH}$ 8, $500 \mathrm{~mm} \mathrm{NaCl}, 5$ mm EDTA, 2.5 mm EGTA; $1 \times$ cross-linking solution: $2 \mathrm{ml}$ of $5 \times$ cross-linking solution, $6.5 \mathrm{ml}$ of $\mathrm{H}_{2} \mathrm{O}, 1.48 \mathrm{ml}$ of formaldehyde $(37 \%)$ in water] to cells in $10 \mathrm{ml}$ of growth medium. After $10 \mathrm{~min}$ of incubation at room temperature with gentle shaking, one-tenth of stop solution ( $1.25 \mathrm{~m}$ glycine, $10 \mathrm{~mm}$ Tris) was added, and incubation was continued for $5 \mathrm{~min}$ at room temperature. After $10 \mathrm{~min}$ of incubation at room temperature with gentle shaking, $1 \mathrm{ml}$ of stop solution $(1.25 \mathrm{M}$ glycine, $10 \mathrm{~mm}$ Tris) was added, and incubation was continued for $5 \mathrm{~min}$ at room temperature. Medium was aspirated. Cell lysis was performed on ice. Cross-linked cells were rinsed twice with $5 \mathrm{ml}$ of cold $1 \times$ PBS supplemented with $0.5 \mathrm{~mm}$ EDTA. Cells were spun at $2500 \mathrm{rpm}$ for $5 \mathrm{~min}$. After addition of $1 \mathrm{ml}$ of lysis buffer [ $50 \mathrm{ml}$ of $10 \times$ lysis buffer: $5 \mathrm{ml}$ of 1 M Tris, $\mathrm{pH} 8,12.5 \mathrm{ml}$ of Triton X-100 (10\%), $10 \mathrm{ml}$ of $0.5 \mathrm{M}$ EDTA, 1.25 $\mathrm{ml}$ of $0.2 \mathrm{M}$ EGTA, $21.2 \mathrm{ml}$ of $\mathrm{H}_{2} \mathrm{O}$; $1 \times$ lysis solution: add $1.25 \mathrm{ml}$ of Na-butyrate (NaBut), $10 \mathrm{ml}$ of $\beta$-glycerophosphate, $500 \mu \mathrm{l}$ of $\mathrm{Na}$ orthovanadate] and incubation on ice for $20 \mathrm{~min}$, lysates were spun at $3000 \mathrm{rpm}$ for $4 \mathrm{~min}$. One millimeter of washing buffer $(20 \mu \mathrm{l}$ of $5 \mathrm{M} \mathrm{NaCl}$ in $1 \mathrm{ml}$ of sonication buffer; $500 \mathrm{ml}$ of sonication buffer: $471 \mathrm{ml}$ of $\mathrm{H}_{2}$, $5 \mathrm{ml}$ of $1 \mathrm{M}$ Tris, pH 8, $10 \mathrm{ml}$ of $5 \mathrm{M} \mathrm{NaCl}, 1 \mathrm{ml}$ of $500 \mathrm{~mm}$ EDTA, $1.25 \mathrm{ml}$ of $200 \mathrm{~mm}$ EGTA, $1.25 \mathrm{ml}$ of $4 \mathrm{M}$ NaBut, $10 \mathrm{ml}$ of $\beta$-glycerophosphate, $500 \mu \mathrm{l}$ of Na-orthovanadate, 2 tablets of protease inhibitor per $100 \mathrm{ml}$ ) was added, and lysates were spun at $3000 \mathrm{rpm}$ for $4 \mathrm{~min}$. Cross-linked cells were sonicated three to four times for $2 \mathrm{~min}$ at maximum amplitude with an intermediate resting time of $10 \mathrm{~min}$ between the sonication cycles using a UP50H Ultrasonic Processor. Alternatively, cross-linked cells were sonicated for 18 cycles of $30 \mathrm{~s}$ on/30 s off with high output setting, using the Bioruptor (Diagenode). After sonication, the chromatin was spun at maximum speed for $30 \mathrm{~min}$ at $10^{\circ} \mathrm{C}$. SDS was diluted with sonication buffer to $0.1 \%$. Then, samples were concentrated in VIVASPIN columns at $3400 \mathrm{rpm}$ at $15^{\circ} \mathrm{C}$ until the final volume was between 0.5 to $0.8 \mathrm{ml}$. For preclearing of chromatin, the samples were adjusted to radioimmunoprecipitation assay (RIPA) buffer (for $300 \mathrm{ml}$ of RIPA buffer: $158.8 \mathrm{ml}$ of $\mathrm{H}_{2} \mathrm{O}, 75 \mathrm{ml}$ of $1 \mathrm{M} \mathrm{LiCl}, 30 \mathrm{ml}$ of $10 \% \mathrm{NP}-40,30 \mathrm{ml}$ of $10 \%$ deoxycholic acid (DOC), $3 \mathrm{ml}$ of $1 \mathrm{M}$ Tris, $\mathrm{pH}$ 8, $600 \mu \mathrm{l}$ of EDTA, $1.5 \mathrm{ml}$ of EGTA, $750 \mathrm{ml}$ of NaBut, $300 \mu$ l of orthovanadate; final concentrations of $1 \%$ Triton X-100, $140 \mathrm{~mm} \mathrm{NaCl}, 0.1 \%$ DOC); BSA (20 mg/ml; $1 \%$ final 
a

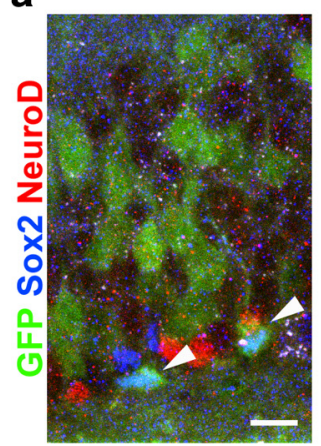

b

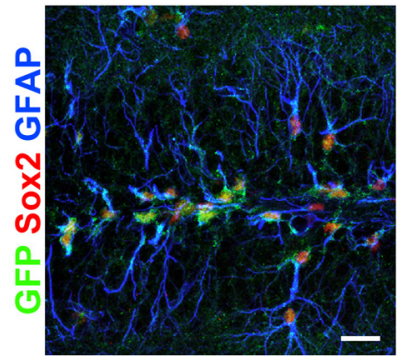

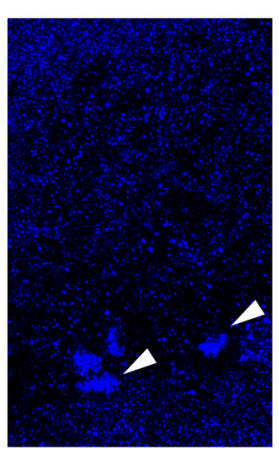
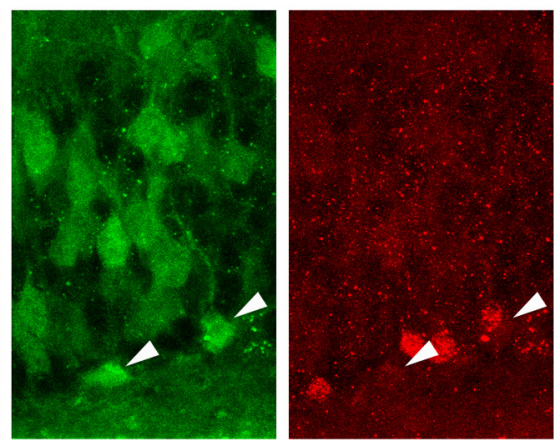

C
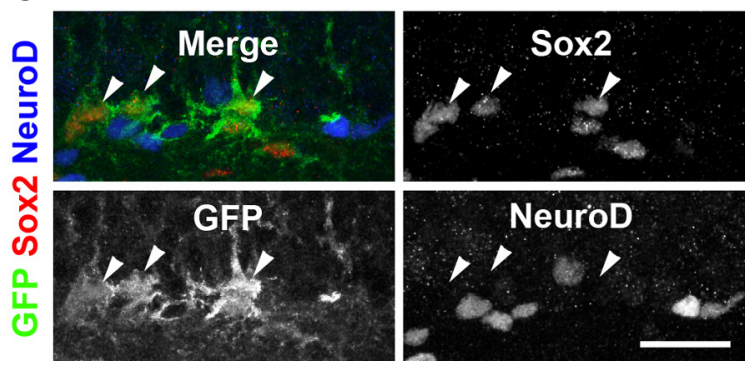

Figure 1. a, Analysis of adult $\mathrm{Tg}(\mathrm{Cp}$-EGFP)25Gaia mice shows that Sox2-expressing cells (blue) in the SGZ of the dentate gyrus are positive for the GFP reporter (green, arrowheads). In contrast, adjacent NeuroD-expressing cells (red) are GFP reporter negative. GFP expression is also present in scattered cells of the dentate granule cell layer. Scale bar, $10 \mu \mathrm{m}$. $\boldsymbol{b}$, Analysis of adult Hes5-GFP mice reveals activity of the GFP reporter (green) in Sox2-positive (red) radial glia-like and nonradial stem cells. GFAP is shown in blue. Scale bar, $20 \mu \mathrm{m}$. c, Hes5-GFP reporter is active in Sox2-positive cells (red, arrowheads) but not in NeuroDexpressing cells (blue).
For quantitative PCRs, the following primers were used to amplify regions within the Sox 2 promoter, which contain a potential RBPJ $\kappa$-binding site (numbers correspond to the predicted RBPJ $\kappa$-binding site; see above): \#1 forward, GGCGAGTGGTTAAACAGAGC; reverse, GCGAGAACTAGCCAAGCATC; \#3 forward, GCAGTGAGAGGGGTGGACTA; reverse, GCTCCGCTCATTGTCCTTAC; \#4 forward, CAATGGGAGATCGGCTAAAA; reverse, ACAGGCACGGTGGTAGTCAC; \#5 forward, CTTGTGTCAGGGTTGGGAGT; reverse, CCTGGCTTCCGTGTCATC. Primers for Hes1 were as follows: Hes1 (forward, ACACCGGACAAACCAAAGAC; reverse, GTCACCTCGTTCATGCACTC). Primers for the amplification of an RBPJ $\kappa$-unrelated region within the Sox 2 promoter were as follows: forward, CGCAGGTAAGCAGGGATTTCT; reverse, CGCTTGCTTTTGGAGAGGAAC.

For detection, Brilliant II Fast SYBR Green qPCR Master Mix (Agilent) was used according to the manufacturer's protocol. Three independent experiments were performed.

Statistical analysis. Unpaired Student's $t$ test was used for analysis of most experiments. Before the $t$ test, an $F$ test was performed. In those cases, in which the $F$ test resulted in a difference in the variances, a Mann-Whitney-Wilcoxon rank sum test was used. Differences were considered statistically significant at $p<0.05$. All data are presented as mean \pm SEM. concentration) and $1 \mu \mathrm{l}$ of salmon sperm $(10 \mathrm{mg} / \mathrm{ml})$ were added. Twenty microliters of Sepharose A/G (50:50; previously washed) and 2 $\mu \mathrm{g}$ of appropriate IgG antibody were used per sample. Samples were rotated for $2 \mathrm{~h}$ at $4^{\circ} \mathrm{C}$. Samples were spun at $3000 \mathrm{rpm}$ for $2 \mathrm{~min}$, and the supernatant was collected. Fifty microliters $\left(+50 \mu \mathrm{l}\right.$ of $\mathrm{H}_{2} \mathrm{O}$; overnight at $65^{\circ} \mathrm{C}$, add $5 \mu \mathrm{l}$ of proteinase $\mathrm{K}$ and incubate for $2 \mathrm{~h}$ at $55^{\circ} \mathrm{C}$ ) were used as an input control. Chromatin was precipitated using 1-5 $\mu \mathrm{g}$ of antibody against the following proteins: Notch1 (rabbit; Abcam), RBPJ $\kappa$ (goat; Santa Cruz Biotechnology), and RBPJ $\kappa$ clone RBP1F1 (rat). BSA (20 $\mathrm{mg} / \mathrm{ml}$ ) was added to a final concentration of $1 \%$ together with $1 \mu \mathrm{l}$ of salmon DNA and a 50:50 mixture of Sepharose A/G. Samples were rotated for $2 \mathrm{~h}$ at $4^{\circ} \mathrm{C}$ and spun at $3000 \mathrm{rpm}$ for $2 \mathrm{~min}$. The supernatant was discarded, and the complex of chromatin antibody-protein A/G was washed with three times with RIPA buffer, three times with RIPA buffer supplemented with $1 \mathrm{M} \mathrm{NaCl}$, two times with $\mathrm{LiCl}$ buffer $\left(181 \mathrm{ml}^{\text {of } \mathrm{H}_{2}} \mathrm{O}\right.$, $2 \mathrm{ml}$ of $10 \%$ DOC, $2 \mathrm{ml}$ of $1 \mathrm{M}$ Tris, $\mathrm{pH} 8,5.6 \mathrm{ml}$ of $5 \mathrm{M} \mathrm{NaCl}, 2 \mathrm{ml}$ of $100 \%$ Triton X-100, $2 \mathrm{ml}$ of $10 \%$ SDS, $400 \mu \mathrm{l}$ of $0.5 \mathrm{~m} \mathrm{EDTA,} 250 \mu \mathrm{l}$ of $0.2 \mathrm{M}$ EGTA, $500 \mu \mathrm{l} 4 \mathrm{~m}$ of NaBut, $4 \mathrm{ml}$ of $1 \mathrm{~m} \beta$-glycerophosphate, $200 \mu \mathrm{l}$ of Na-orthovanadate), and two times with $1 \times$ Tris-EDTA (TE) buffer. Elution buffer 1 ( $3.3 \mathrm{ml}$ of TE, $0.6 \mathrm{ml}$ of $10 \%$ SDS, $10 \mu \mathrm{l}$ of NaBut, $80 \mu \mathrm{l}$ of glycerophosphate, $24 \mu \mathrm{l}$ of $5 \mathrm{M} \mathrm{NaCl}$ ) and buffer II ( $3.7 \mathrm{ml}$ of TE, $0.2 \mathrm{ml}$ of $10 \%$ SDS, $10 \mu \mathrm{l}$ of NaBut, $80 \mu \mathrm{l}$ of glycerophosphate, $24 \mu \mathrm{l}$ of $5 \mathrm{M}$ $\mathrm{NaCl}$ ) were prepared. Elution was performed with $200 \mu$ l of elution buffer 1, and samples were rotated for $20 \mathrm{~min}$ at room temperature. Samples were spun at $3000 \mathrm{rpm} 2 \mathrm{~min}$, and supernatants were recovered. Elution, rotation, and spinning were repeated with elution buffer II. Cross-linking was reverted overnight at $65^{\circ} \mathrm{C}$. A total of 2.5 $\mu l$ of proteinase $\mathrm{K}(20 \mathrm{mg} / \mathrm{ml})$ was added, and the samples were incubated for $2 \mathrm{~h}$ at $55^{\circ} \mathrm{C}$. After phenol/chloroform extraction, samples were precipitated with 2.5 vol of $100 \% \mathrm{EtOH}, 150 \mathrm{~mm} \mathrm{NaCl}$ (final concentration), and $2.5 \mu \mathrm{l}$ of glycogen $(20 \mathrm{mg} / \mathrm{ml})$ overnight at $-20^{\circ} \mathrm{C}$. Samples were spun down at $13,000 \mathrm{rpm}$ at $4{ }^{\circ} \mathrm{C}$, and the pellets were washed with $80 \%$ of EtOH, dried, and resuspended in $30 \mu \mathrm{l}$ of water or $1 \times$ TE buffer. Quantitative real-time PCR was used to analyze the precipitated DNA.

\section{Results}

Notch signaling is differentially active in stem cells and neuronally committed cells

In canonical Notch signaling, binding of ligands to the Notch receptor results in the cleavage of the NICD. NICD then translocates to the nucleus to interact with the transcriptional regulator RBPJ $\kappa$ to induce the expression of target genes (Baron, 2003 ). To determine the activity of Notch/ RBPJ $\kappa$ signaling in the adult hippocampal neurogenic niche, we analyzed two distinct Notch/RBPJ $\kappa$ signaling reporter mouse lines. $\mathrm{Tg}(\mathrm{Cp}$ EGFP)25Gaia mice (Duncan et al., 2005; Mizutani et al., 2007) and Hes5-GFP transgenic mice (Basak and Taylor, 2007) express enhanced GFP (EGFP) under the control of multimerized RBPJ $\kappa$-binding sites and the Hes5 promoter, respectively. Both transgenic mouse lines have been successfully used to determine canonical Notch signaling activity in vivo (Duncan et al., 2005; Basak and Taylor, 2007; Mizutani et al., 2007). To determine the activity of canonical Notch signaling in NSCs and neuronally committed cells, we stained hippocampal tissue from these reporter mice for the transcription factors SOX2 and NeuroD, which are sequentially expressed in the hippocampal neurogenic lineage where they control NSC maintenance (Favaro et al., 2009; Kuwabara et al., 2009) and neuronal fate commitment (Gao et al., 2009; Kuwabara et al., 2009), respectively. In both reporter mouse lines, EGFP was expressed in Sox2-positive NSCs in the SGZ (Fig. 1). Quantification of Sox2 EGFP coexpression in Hes5-GFP transgenic mice revealed reporter activity in the vast majority of Sox2-positive cells in the SGZ (94.8 $\pm 1.9 \%$ ) (Fig. 1b,c). No EGFP expression was detected in NeuroD-expressing cells in the SGZ in either of the two reporter lines (Fig. 1). Thus, EGFP reporter activity in both transgenic mouse lines consistently indicate that 
a

5 days Tamoxifen 21 days, 60 days survival
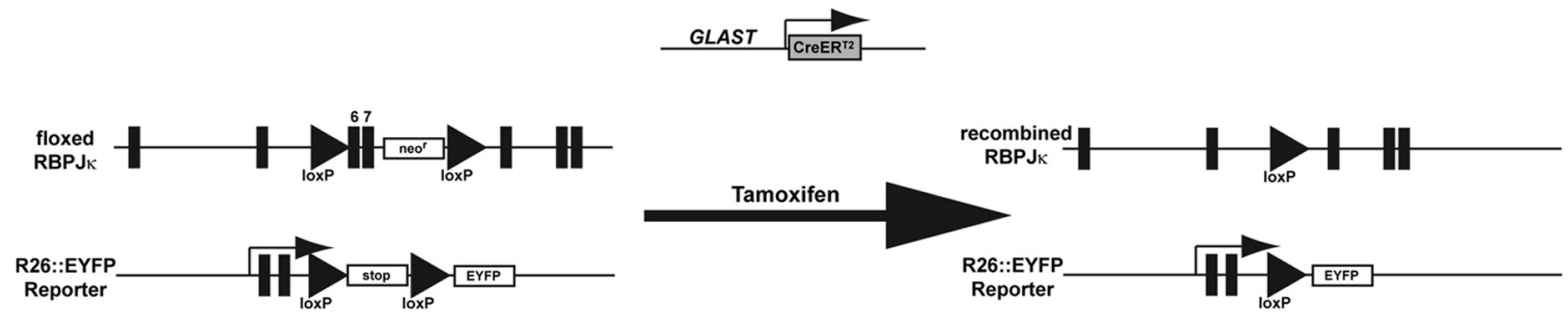

b

b Control
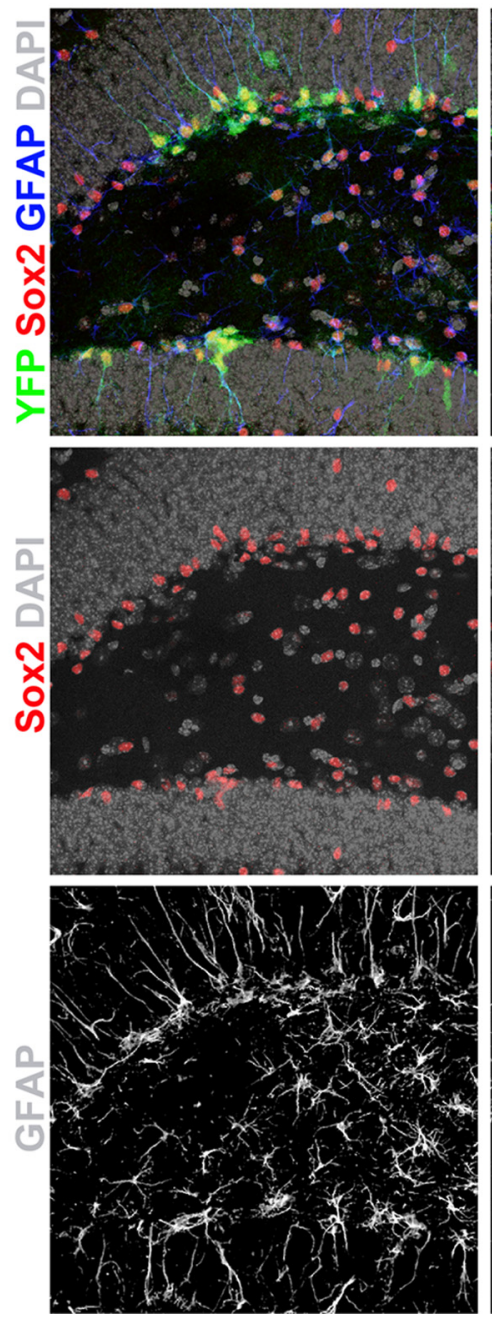

RBPJK-CKO
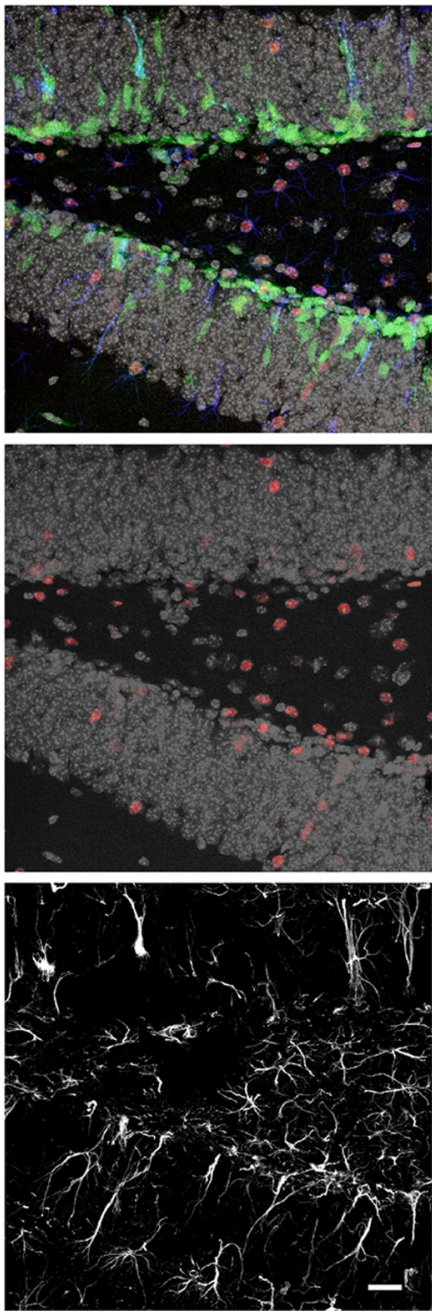

C

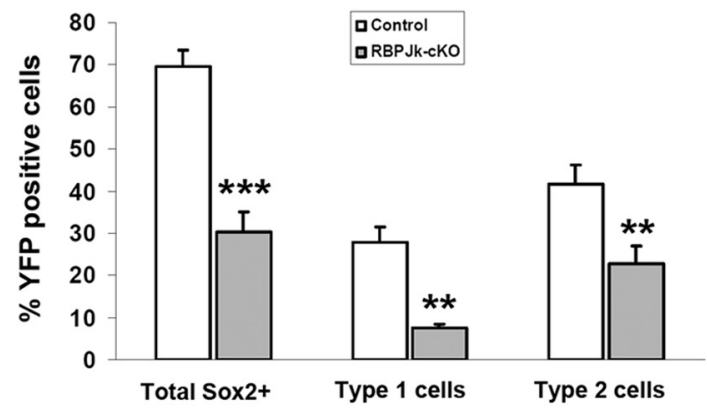

d

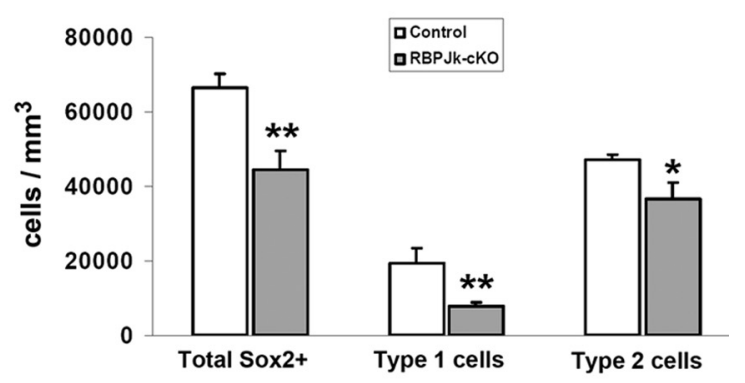

Figure 2. a, Experimental strategy to study the role of RBPJ $\kappa$ signaling in adult hippocampal stem cells and neurogenesis. GLAST::CreERT2; RBPJ $\kappa^{\text {loxp/loxp; }}$ R26::EYFP (RBPJ $\kappa$-cK0) and GLAST::CreERT2; RBPJ $\kappa^{\text {loxp/+ }}$; R26::EYFP (control) were treated for $5 \mathrm{~d}$ with TAM to induce recombination in the RBPJ $\kappa$ and the R26::EYFP locus. Animals were analyzed 21 or $60 \mathrm{~d}$ after the final TAM injection. $\boldsymbol{b}-\boldsymbol{d}$, Loss of RBPJ $\boldsymbol{\kappa}$ in radial glia-like stem cells decreases stem cell numbers 3 weeks after TAM-induced recombination. $\boldsymbol{b}$, Representative confocal images of $\mathrm{RBPJ}_{\kappa}$-cKO and control mice. A large proportion of YFP-positive recombined cells (green) in RBPJ $\kappa$-cKO does not express Sox2 (red) and GFAP (blue) and does not display a radial glia-like morphology. Staining for Sox2 shows reduced density of Sox2 cells in the SGZ of RBPJ $K$-CKO. Staining for GFAP demonstrates an overall reduction in radial glia-like stem cells in the

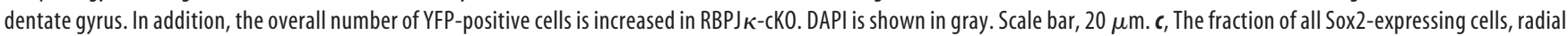
glia-like stem cells (type 1 cells, identified by Sox2/GFAP expression and radial morphology), and nonradial stem cells (type 2 cells, identified by Sox2 expression and localization in the SGZ) among the recombined cells is significantly decreased in $\mathrm{RBPJ}_{K}$-cKO mice. ${ }^{* *} p<0.01 ;{ }^{* * *} p<0.001$. $\boldsymbol{d}$, The density of Sox2-expressing cells, radial glia-like stem cells (type 1 cells), and nonradial stem cells (type 2 cells) in the SGZ is significantly decreased in RBPJ $K$-cKO mice. ${ }^{*} p<0.05 ;{ }^{* *} p<0.01$ ).

Notch signaling through RBPJ $\kappa$ is active in Sox2-positive stem cells and that Notch signaling is inactivated in parallel with the loss of Sox 2 expression, the initiation of NeuroD expression, and the neuronal fate commitment of NSCs. The additional reporter activity, which was observed in scattered cells in the granule cell layer of $\mathrm{Tg}$ (Cp-EGFP)25Gaia mice (Fig. 1a) raises the possibility that canonical Notch signaling may also be active in a subset of mature granule neurons. 


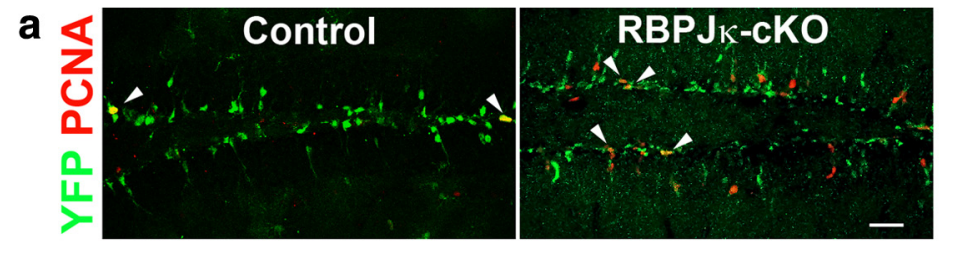

d
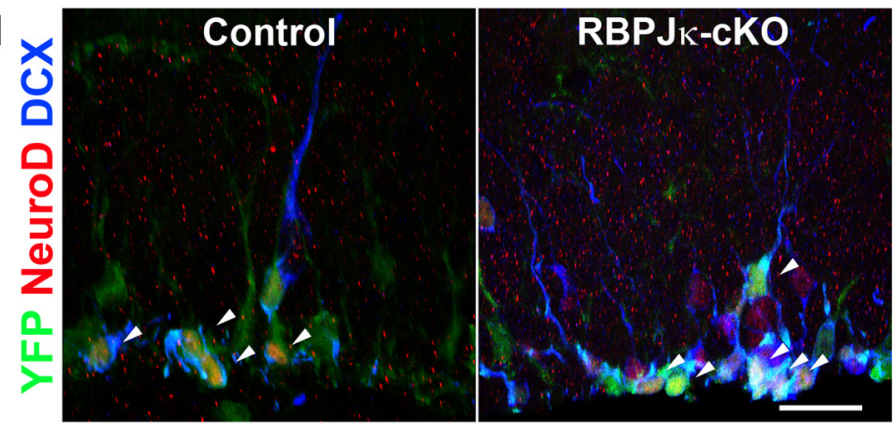

g

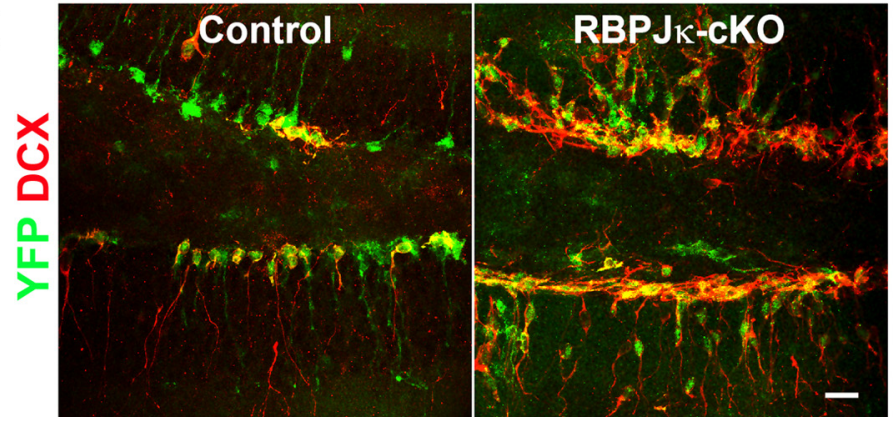

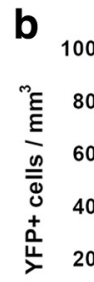
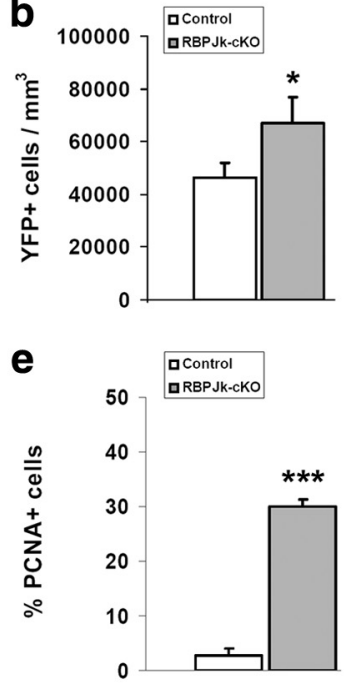

h

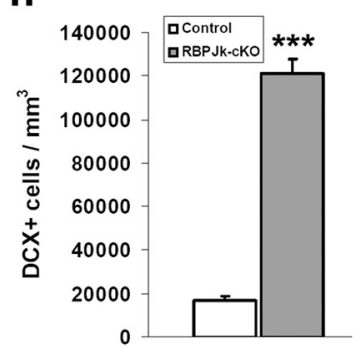

C

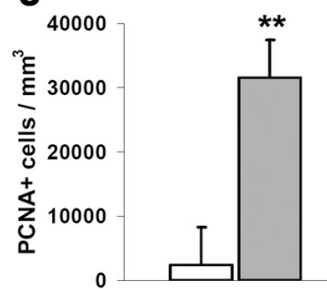

f

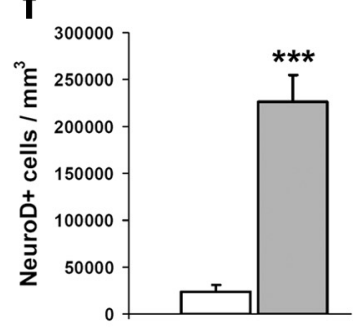

Figure 3. Loss of RBPJ $\kappa$ in radial glia-like stem cells increases neurogenesis 3 weeks after recombination. $\boldsymbol{a}$, Representative confocal images of RBPJ $\kappa$-cKO and control mice. The overall number of proliferating cells identified by expression of PCNA (red) as well as the fraction of PCNA-positive cells among the YFP-positive recombined cells ( $\mathrm{green}$, arrowheads) is increased in RBPJ $\kappa$-cKO mice. Scale bar, $20 \mu \mathrm{m} . \boldsymbol{b}$, Quantification of the density of YFP-positive cells. ${ }^{*} p<0.01$. $\boldsymbol{c}, \boldsymbol{e}$, Quantification of the density of PCNA positive cells $(\boldsymbol{c})\left({ }^{* *} p<0.01\right)$ and the fraction of PCNA positive cells $(\boldsymbol{e})$ among the recombined cells $\left({ }^{* *} p<0.001\right)$. $\boldsymbol{d}$, The overall number of NeuroD-expressing newly generated neurons (red) as well as the fraction of NeuroD-positive immature neurons among the YFP-positive recombined cells (green, arrowheads) is strongly increased in RBPJ $\kappa$-cKO mice. DCX is shown in blue. Scale bar, $20 \mu \mathrm{m}$. $f$, Quantification of the density of NeuroD-positive cells ${ }^{* * *} p<$ 0.001). $\boldsymbol{g}$, The overall number of newly generated neurons identified by expression of DCX (red) as well as the fraction of DCX-positive immature neurons among the YFP-positive recombined cells (green) is strongly increased in RBPJ $\kappa$-cKO mice. Note the pronounced increase in the overall number of YFP-expressing cells. Scale bar, $20 \mu \mathrm{m}$. $\boldsymbol{h}, \mathrm{Quantification}$ of the density of DCX-positive immature neurons and the fraction of DCX-expressing cells among the recombined cells ( $\left.{ }^{* * *} p<0.001\right)$.

Impaired stem cell maintenance and transient enhancement of neurogenesis after inactivation of RBPJK

To test the role of Notch/RBPJ $\kappa$ signaling in adult hippocampal stem cell maintenance in vivo, we inactivated RBPJ $\kappa$ in NSCs of the adult hippocampus. We took advantage of the BAC transgenic mouse line that expresses TAM-dependent Cre recombinase $\left(\mathrm{CreER}^{\mathrm{T} 2}\right)$ under the control of the GLAST promoter (GLAST::CREERT2). In these mice, the CreER ${ }^{\mathrm{T} 2}$ transgene is strongly expressed during adulthood in Sox2-expressing radial glia-like stem cells of the adult hippocampus (type 1 cells) (Slezak et al., 2007). To generate mice, in which Notch signaling through RBPJ $\kappa$ can be conditionally ablated in type 1 cells, GLAST::CreER ${ }^{\mathrm{T} 2}$ mice were crossed with mice carrying conditional alleles for RBPJ $\kappa$ $\left(\mathrm{RBPJ} \kappa^{\text {loxp/loxp }}\right.$ ) (Han et al., 2002) and R26::EYFP reporter mice (Srinivas et al., 2001) to generate GLAST::CreERT2; RBPJ $\kappa^{\text {loxp/loxp; }}$ R26::EYFP (RBPJ $\kappa$-cKO) (Fig. 2a). GLAST::CreERT2; RBPJ $\kappa^{\text {loxp/++; }}$ R26::EYFP (control; i.e., mice in which only one RBPJ $\kappa$ allele can be deleted after induction of Cre recombinase activity) served as controls.

Twelve-week-old animals were treated for 5 consecutive days with TAM to induce recombination in the radial glia-like NSCs. Animals were killed 3 weeks after the final TAM injection. Intriguingly, the fraction of Sox2-expressing cells among the re- combined cells, which were identified on the basis of YFP expression, was greatly reduced in RBPJ $\kappa$-cKO (RBPJ $\kappa$-cKO, $30.32 \pm 4,87 \%$ vs control, $69.60 \pm 3.67 \% ; p<0.001$ ) (Fig. $2 b, c$ ). The Sox2-expressing stem cell population in the SGZ consists of quiescent or slowly dividing multipotent stem cells with a radial glia-like morphology (type 1 cells) and of nonradial stem/precursor cells (type 2 cells), which show higher levels of proliferation (Kempermann et al., 2004; Suh et al., 2007). We identified these populations using the following criteria: radial glia-like NSCs were identified on the basis of Sox $2 /$ GFAP coexpression and their radial morphology, whereas nonradial stem/precursor cells were identified on the basis of the expression of Sox 2 and their location in the SGZ (Suh et al., 2007). Based on these criteria, we found that loss of RBPJ $\kappa$ signaling reduced both the proportion of radial glia-like NSCs (RBPJ $\kappa$-cKO, $7.54 \pm 0.93 \%$ vs control, $27.90 \pm$ $3.63 \%$; $p<0.01$ ) (Fig. $2 c$ ) and the proportion of nonradial stem/ precursor cells (RBPJ $\kappa$-cKO, $22.78 \pm 4.17 \%$ vs control, $41.70 \pm$ $4.32 \%$; $p<0.01$ ) among all YFP-expressing cells (Fig. $2 c$ ). Importantly, the total number of Sox2-expressing cells (RBPJ $\kappa$ cKO, 44,390 $\pm 5,154 / \mathrm{mm}^{3}$ vs control, 66,564 $\pm 3,646 / \mathrm{mm}^{3} ; p<$ $0.01)$, radial glia-like NSCs (RBPJ $\kappa-\mathrm{cKO}, 7,801 \pm 928 / \mathrm{mm}^{3}$ vs control, 19,466 $\left.\pm 3,831 / \mathrm{mm}^{3} ; p<0.01\right)$, and nonradial stem/ precursor cells $\left(\mathrm{RBPJ} \kappa-\mathrm{cKO}, 36,589 \pm 4,413 / \mathrm{mm}^{3}\right.$ vs control, 
$\left.47,097 \pm 1,231 / \mathrm{mm}^{3} ; p<0.05\right)$ were significantly reduced in the SGZ of RBPJ $\kappa$-cKO mice (Fig. $2 b, d$ ). Hence, loss of RBPJ $\kappa$ in NSCs decreases the NSC pool in the hippocampal neurogenic niche.

Despite the reduction in the NSC pool, higher numbers of YFP-positive cells were observed in RBPJ $\kappa$-cKO compared with control mice (RBPJ $\kappa$-cKO, 66,839 $\pm 9,785 / \mathrm{mm}^{3}$ vs $46,196 \pm$ control, 5,662/ $\mathrm{mm}^{3} ; p<0.05$ ) (Fig. 3b). Moreover, RBPJ $\kappa-\mathrm{cKO}$ showed an overall increase in the number of cells expressing the proliferation marker PCNA $\left(\mathrm{RBPJ} \kappa-\mathrm{cKO}, 31,526 \pm 5,816 / \mathrm{mm}^{3}\right.$ vs control, 2,468 $\left.\pm 797 / \mathrm{mm}^{3} ; p<0.01\right)$ and an increased fraction of proliferating cells among the YFP-positive cells (RBPJ $\kappa-\mathrm{cKO}$, $30.0 \pm 1.3 \%$ vs control, $2.8 \pm 1.3 \% ; p<0.001$ ), indicating that inactivation of RBPJ $\kappa$ in NSCs increased cell genesis (Fig. $3 a, c, e)$. In RBPJ $\kappa$-cKO, a much higher proportion of Sox 2 cells expressed PCNA (RBPJ $\kappa$-cKO, $29.2 \pm 12.3$ vs control, $3.3 \pm 1.7 ; p<0.05$ ), demonstrating that the remaining NSCs were recruited into proliferation. RBPJ $\kappa$-cKO mice showed a fourfold to fivefold increase in the fraction of DCX-expressing immature neurons among the recombined cells ( $\mathrm{RBPJ} \kappa-\mathrm{cKO}, 81.87 \pm 5.88 \%$ vs control, $25.47 \pm 5.43 \% ; p<0.001)$ and in the total number of DCXpositive (RBPJ $\kappa$-cKO, 121,345 $\pm 6,432 / \mathrm{mm}^{3}$ vs control, $16,871 \pm 1,908 / \mathrm{mm}^{3} ; p<0.001$ ) and NeuroD-positive (RBPJ $\kappa$ $\mathrm{cKO}, 22,5851 \pm 28,819 / \mathrm{mm}^{3}$ vs control, $24,026 \pm 6,906 / \mathrm{mm}^{3}$; $p<0.001$ ) immature neurons (Fig. $3 d, f-h$ ). A great proportion of the neurons that were generated in excess in response to loss of RBPJ $\kappa$ showed long-term survival, as evidenced by the fact that the density of YFP-labeled mature neurons was significantly increased in RBPJ $\kappa$-cKO 2 months after recombination (RBPJ $\kappa$-cKO, 17,383 \pm 3,870 cells $/ \mathrm{mm}^{3}$ vs $4,405 \pm$ control, 2,$\left.042 ; p<0.01\right)$.

Surprisingly, we also observed alterations in the behavior of YFP-negative cells in the dentate gyrus of RBPJ $\kappa$-cKO. In fact, $\mathrm{RBPJ} \kappa$-cKO showed greatly increased numbers of YFP-negative, DCX-expressing immature neurons (RBPJ $\kappa$-cKO, 39,924 \pm 9,476 cells $/ \mathrm{mm}^{3}$ vs control, 7,595 \pm 327 cells $\left./ \mathrm{mm}^{3} ; p<0.05\right)$ and YFP-negative proliferating cells $(\mathrm{RBPJ} \kappa$-cKO, 11,619 \pm 3,791 cells $/ \mathrm{mm}^{3}$ vs control, $1,040 \pm 248$ cells $/ \mathrm{mm}^{3} ; p<0.05$ ) (Fig. 4). Similar to the YFP-positive cell compartment, a high percentage of YFP-negative NSCs was found to be proliferating in RBPJ $\kappa$-cKO $(\sim 30 \%)$. Moreover, the estimated density of YFPnegative type 1 and type 2 cells was decreased in RBPJ $\kappa$-cKO compared with control (supplemental Table 1, available at www.jneurosci.org as supplemental material). We cannot fully exclude that the lower density of YFP-negative type 1 and type 2 cells is a function of different recombination efficiencies in $\mathrm{RBPJ} \kappa-\mathrm{cKO}$ and control mice. The fact that the density of YFPnegative proliferating cells and of YFP-negative, DCX-positive cells in RBPJ $\kappa-c K O$ exceeds the density of proliferating cells and DCX-positive newborn neurons in control animals, however, strongly indicates that inactivation of RBPJ $\kappa$-cKO affects proliferation and neurogenesis also from cells with intact RBPJ $\kappa$ mediated signaling.

Together, our results demonstrate that conditional ablation of $\mathrm{RBPJ} \kappa$ results in a reduction in the hippocampal NSC pool and an increase in proliferation and the generation of new neurons 3 weeks after recombination. These findings indicate that RBPJ $\kappa$ dependent pathways regulate the balance between stem cell maintenance and differentiation within the adult hippocampal neurogenic niche.

\section{RBPJ $\kappa$ is essential for long-term NSC maintenance in the adult hippocampus}

Next, we sought to determine the long-term consequences of loss of RBPJ $\kappa$ signaling in adult NSCs on hippocampal neurogenesis.
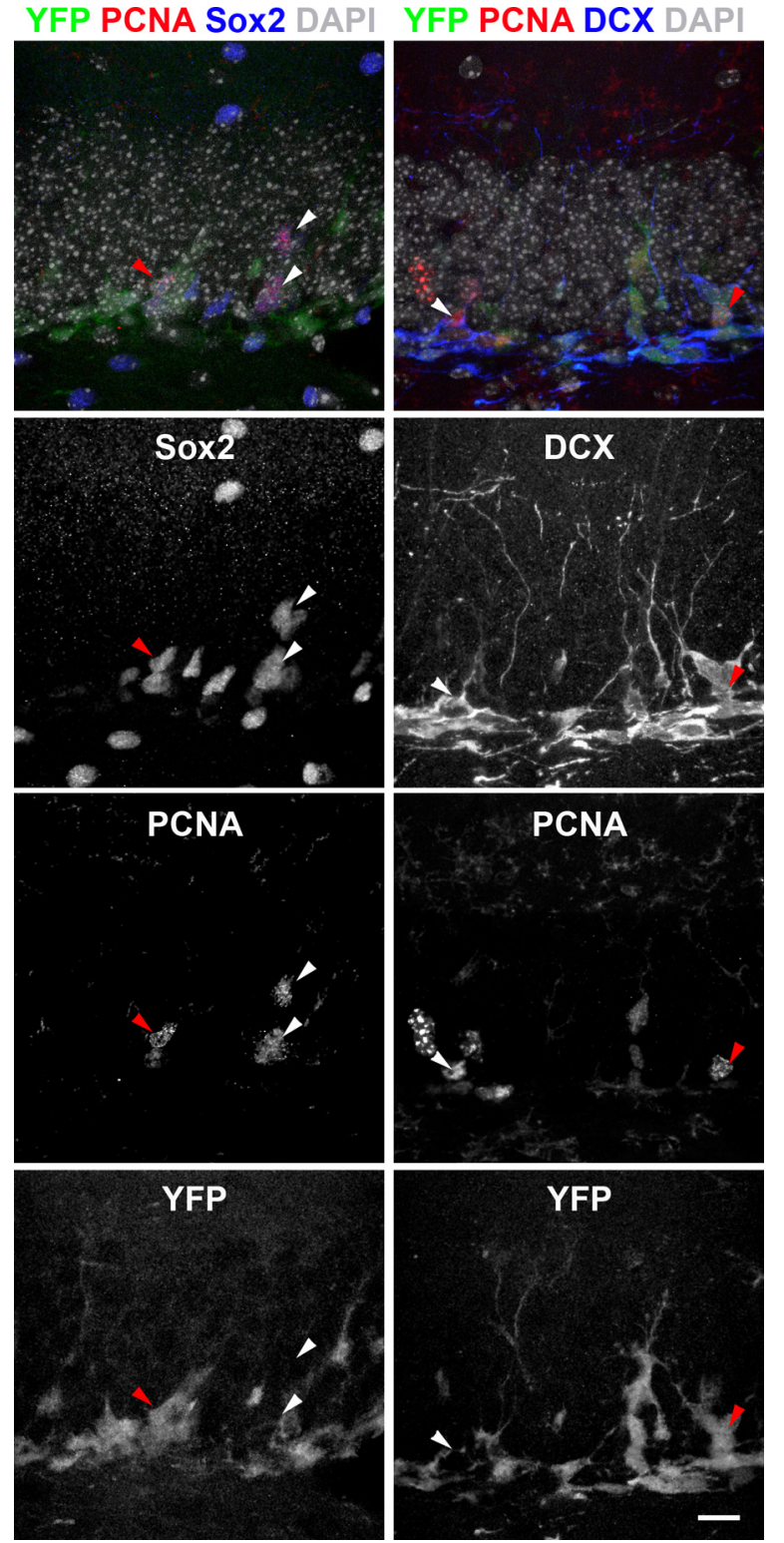

Figure 4. Loss of RBPJ $\kappa$ in radial glia-like stem cells increases proliferation in YFP-positive and YFP-negative cells. Proliferating Sox2-positive stem cells (blue) are present in the YFPpositive (green, red arrowhead) and YFP-negative (white arrowhead) compartment (left). Similarly, proliferating DCX-positive immature neurons are found among YFP-positive (red arrowhead) and YFP-negative cells (right). PCNA is shown in red, and DAPI is shown in gray. Scale bar, $20 \mu \mathrm{m}$.

To this end, 12 -week-old RBPJ $\kappa$-cKO and control mice were treated for 5 consecutive days with TAM. Mice were examined 2 months after the induction of recombination. Immunostaining with GFAP and Sox 2 revealed an even more pronounced decrease at this time point in the density of Sox 2 -expressing cells (RBPJ $\kappa$ $\mathrm{cKO}, 23,928 \pm 4,788 / \mathrm{mm}^{3}$ vs $\left.59,805 \pm 4,852 / \mathrm{mm}^{3} ; p<0.01\right)$ and radial glia-like stem cells in RBPJ $\kappa-\mathrm{cKO}(\mathrm{RBPJ} \kappa-\mathrm{cKO}$, $5,503 \pm 1,005 / \mathrm{mm}^{3}$ vs control, $\left.16,386 \pm 2,147 / \mathrm{mm}^{3} ; p<0.01\right)$ (Fig. $5 a, b$ ). In striking contrast to the 3 week time point, neurogenesis was almost absent in RBPJ $\kappa$-cKO as evidenced by the almost complete lack of PCNA-positive proliferating cells (Fig. $5 f$ ) and strong reduction in NeuroD- and DCX-positive cells (RBPJ $\kappa$-cKO, 1,408 $\pm 466 / \mathrm{mm}^{3}$ vs control, 13,687 $\pm 4,296 /$ $\mathrm{mm}^{3} ; p<0.05$ ) (Fig. $5 d, e$ ) in the dentate gyrus of RBPJ $\kappa-\mathrm{cKO}$ mice. Consistent with these findings, the fraction of Sox2- 
a
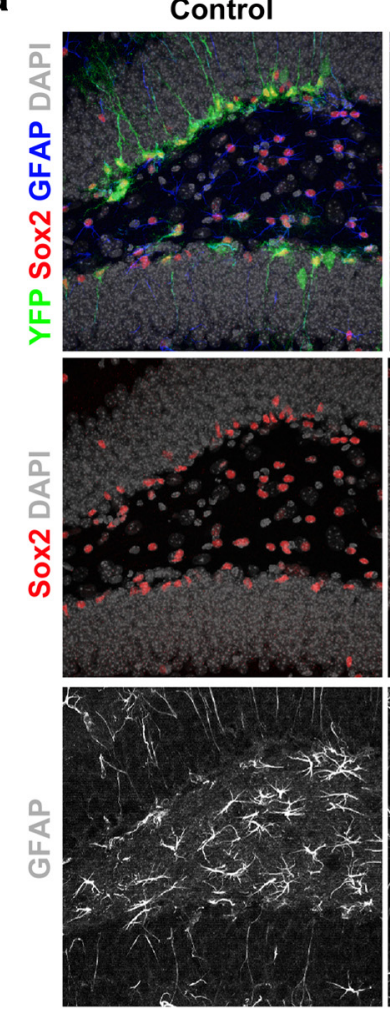

d

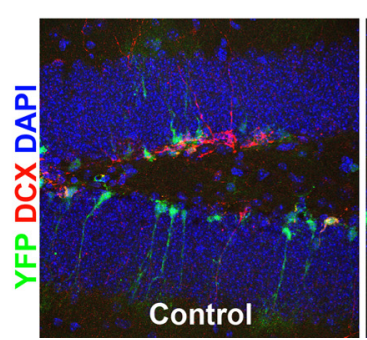

RBPJK-cKO
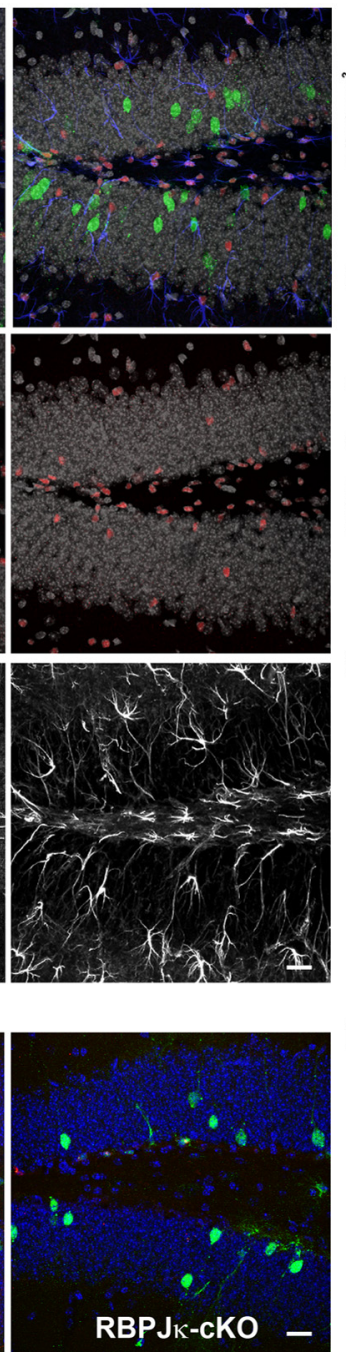

b

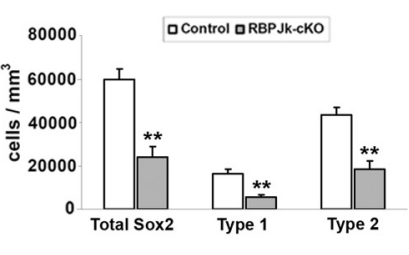

C
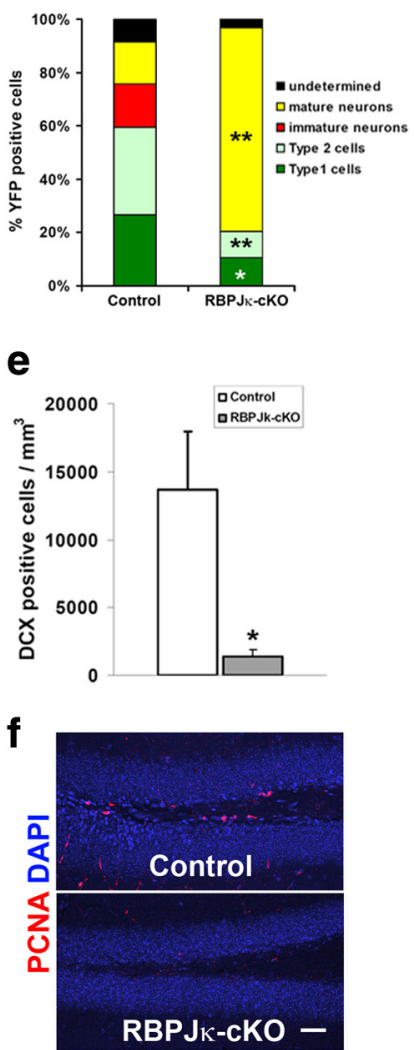

Figure 5. Loss of RBPJ $\kappa$ in radial glia-like stem cells decreases hippocampal neurogenesis and leads to persistent loss of Sox2-expressing stem cells 2 months after recombination. $\boldsymbol{a}$, Representative confocal images of RBPJ $\kappa$-cKO (right) and control mice (left). In RBPJ $\kappa$-cKO mice, YFP-positive recombined cells (green) do not express Sox2 (red) or GFAP (blue). Staining for GFAP demonstrates a strong reduction in the number of radial glia-like stem cells in the dentate gyrus. The vast majority of YFP-positive cells in RBPJ $\kappa$-cKO is located in the granule cell layer. DAPI is shown in gray. Scale bar, $20 \mu \mathrm{m} . \boldsymbol{b}$, Sox2-expressing cells, radial glia-like stem cells (type 1 cells), and nonradial stem cells (type 2 cells) are depleted from the SGZ of the dentate gyrus in RBPJ $\kappa$-cKO mice $\left({ }^{* *} p<0.01\right)$. c, Phenotyping of YFP-positive cells demonstrates that the vast majority recombined radial glial like stem cells have left the stem cell compartment. Almost no YFP-positive cells express $D C X$, indicating that recombined cells do not contribute to the generation of new neurons 2 months after induction of recombination. Cells were phenotyped according to the following criteria: type 1, Sox2 + GFAP + and radial morphology; type 2, Sox2 + GFAP-; immature neurons, DCX+; mature neurons, NeuN+. $\boldsymbol{d}$, Representative confocal images of $\mathrm{RBPJ}_{\kappa}$-cKO and control mice. In RBPJ $\kappa$-CKO mice, $D C X$-expressing immature neurons (red) are virtually absent. YFP is shown in green, and DAPI is shown in blue. Scale bar, $20 \mu \mathrm{m}$. $\boldsymbol{e}$, The density of DCX-expressing immature neurons in the dentate gyrus is severely reduced $\left({ }^{*} p<0.05\right)$. $\boldsymbol{f}$, Representative confocal images of RBPJ $\kappa$-cKO and control mice. In $\mathrm{RBPJ}_{\kappa}$-cKO mice, proliferating cells identified by the expression of PCNA (red) are virtually absent. DAPI is shown in blue. Scale bar, $20 \mu \mathrm{m}$.

positive radial glia-like stem cells (RBPJ $\kappa$-cKO, $10.7 \pm 3.3 \%$ vs control, $26.7 \pm 8.2 \% ; p<0.05)$ (Fig. $5 c$ ) and nonradial stem/ precursor cells (RBPJ $\kappa$-cKO, $9.6 \pm 2.7 \%$ vs control, $32.8 \pm 3.1 \%$; $p<0.01$ ) (Fig. $5 c$ ) was greatly decreased, and DCX-expressing immature neurons were almost absent (RBPJ $\kappa$-cKO, $0.2 \pm 0.4 \%$ vs control, $16.3 \pm 5.5 \%$; $p<0.01$ ) (Fig. $5 c$ ) among the recombined cells in the dentate gyrus of RBPJ $\kappa$-сKO. The majority of YFP-positive cells were NeuN-expressing neurons (RBPJ $\kappa$-cKO, $76.2 \pm 18.4 \%$ vs control, $15.5 \pm 6.2 \%$; $p<0.01$ ) (Fig. $5 c$ ). Be- cause NeuN is expressed in the hippocampal neurogenic lineage predominantly by mature neurons, it is likely that these YFPpositive neurons were generated early after induction of recombination. The longterm depletion of NSCs and the persistent loss of neurogenesis after inactivation of RBPJ $\kappa$ in adult NSCs strongly support the notion that RBPJ $\kappa$-dependent pathways are essential for stem cell maintenance in the adult hippocampal neurogenic niche.

\section{RBPJ $\kappa$-dependent signaling controls} NSC maintenance directly

The perturbation of maintenance, proliferation, and neurogenesis in recombined and nonrecombined NSCs suggests that the inactivation RBPJ $\kappa$ has a pronounced effect on the hippocampal microenvironment. To investigate, whether RBPJ $\kappa$ also contributes to stem cell maintenance independently of the niche (i.e., through cell-autonomous mechanisms), we sought to determine the effects of RBPJ $\kappa$ inactivation on stem cell maintenance in a "niche-free" system. To this end, we established neurosphere cultures from adult RBPJ $\kappa^{\text {loxp/loxp }}$ mice and performed single-cell neurosphere-forming assays as a measurement of stem cell maintenance and self-renewal. Recombination of the RBPJ $\kappa$ locus was induced via transduction with retrovirus encoding for CRE-GFP fusion protein (Tashiro et al., 2006); retrovirus encoding for GFP served as a control. Previous comparison of CRE-GFP and GFP transduced neurospheres derived from wild-type mice had shown that transduction with CRE-GFP does not impair survival and neurosphere-forming capacity (I. Schaeffner and D. C. Lie, unpublished results). Cells were left for $48 \mathrm{~h}$ to allow for transgene expression and recombination of the RBPJ $\kappa$ locus. Quantitative PCR analysis showed loss of RBPJ $\kappa$ mRNA expression, indicating that expression of CRE-GFP resulted in efficient recombination of the RBPJ $\kappa$ locus (Fig. $6 b$ ).

Although we transduced equal numbers of cells with CRE-GFP virus and control virus, cell numbers in CRE-GFP transduced cultures were repeatedly reduced to $\sim 20 \%$ of controls (data not shown). Single cells were seeded into miniwells $48 \mathrm{~h}$ after transduction. Cultures were visually inspected and marked for the presence of a single-cell and transgene expression $3 \mathrm{~h}$ after seeding (Fig. $6 f$ ). Five days after seeding, a large fraction of control single cells had generated neurospheres $(38.6 \pm 1.8 \%)$. In contrast, CRE-GFP transduced cells showed an $\sim 50 \%$ reduced ability to generate neurospheres in single-cell neurosphere assays (20.5 $\pm 6.4 \%$; $p<0.01$ ) (Fig. 6c). Moreover, the remaining neurospheres were significantly smaller in diame- 
ter (Fig. $6 d, f)$. The formation of primary and secondary neurospheres under clonal cell growth conditions is considered another key characteristic of cultured NSCs. This assay revealed that RBPJ $\kappa$-deficient NSCs were significantly impaired in their ability to generate primary and secondary neurospheres (Fig. 6e). These results indicate that $\mathrm{RBPJ} \kappa$ signaling directly regulates adult NSC maintenance and self-renewal.

Recent work by Favaro et al. (2009) has demonstrated that the transcription factor Sox2 is essential for maintenance of hippocampal NSCs. Intriguingly, we found that a large proportion of CRE-GFP transduced cells were Sox 2 negative, whereas almost all control transduced cells expressed Sox2 (CRE-GFP transduced cells, $65.9 \pm 15.3 \%$ vs control, $95.6 \pm 0.8 \% ; p<0.05$ ) (Fig. 6a). This and our previous observation that $\mathrm{RBPJ} \kappa$-signaling reporters are active in Sox2-expressing hippocampal NSCs in vivo raised the question whether Sox 2 expression may be regulated by RBPJ $\kappa$-dependent signaling. A $5.5 \mathrm{~kb}$ region upstream of the Sox 2 transcription start site in the mouse Sox2 gene has previously been shown to control Sox2 expression in telencephalic NSCs during development (Zappone et al., 2000) and to be sufficient to mimic endogenous Sox 2 expression in the adult neurogenic zones (Suh et al., 2007). Interestingly, in silico analysis of the $5.5 \mathrm{~kb}$ Sox 2 promoter fragment using the MatInspector and Eldorado algorithms of the Genomatix software predicted five RBPJ $\kappa$-binding sites (Fig. 7a). To determine whether Notch signaling can enhance the activity of the Sox 2 promoter, a reporter construct (5.5 kb Sox2-luciferase) was generated in which the expression of the firefly luciferase is controlled by this $5.5 \mathrm{~kb}$ Sox 2 promoter. To investigate whether the Sox 2 promoter is activated by Notch signaling, we determined Sox2-luciferase activity in HEK293 cells after cotransfection with an expression construct for activated Notch (i.e., NICD) at multiple time points after transfection (6-48 h). Compared with control cells, which were transfected with an expression construct for GFP, NICD-transfected cells showed reproducible significant induction of Sox 2 promoter activity starting from $18 \mathrm{~h}$ after transfection (Fig. $7 b$ ). We also sought to determine whether activation of the Notch pathway can stimulate the Sox 2 promoter and Sox 2 expression in an NSC context. To this end, we used neural stem/progenitor cell cultures isolated from the hippocampus of adult mice (Ray and Gage, 2006), as expression plasmids and reporter plasmids can be introduced into these cells with high efficiency via electroporation. RT-PCR, Western blot, and immunocytochemical analysis revealed that Sox 2 was highly ex-

d

f

3h
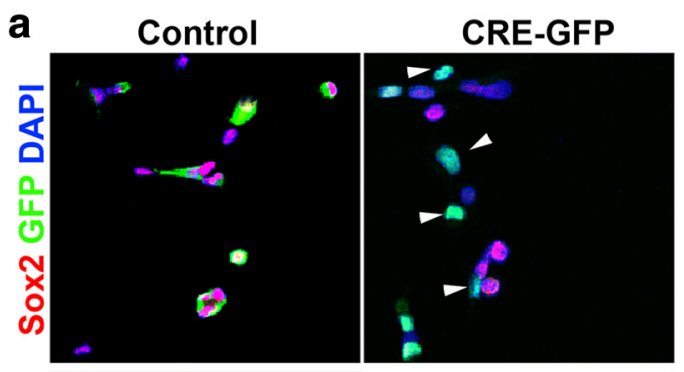

\section{b}
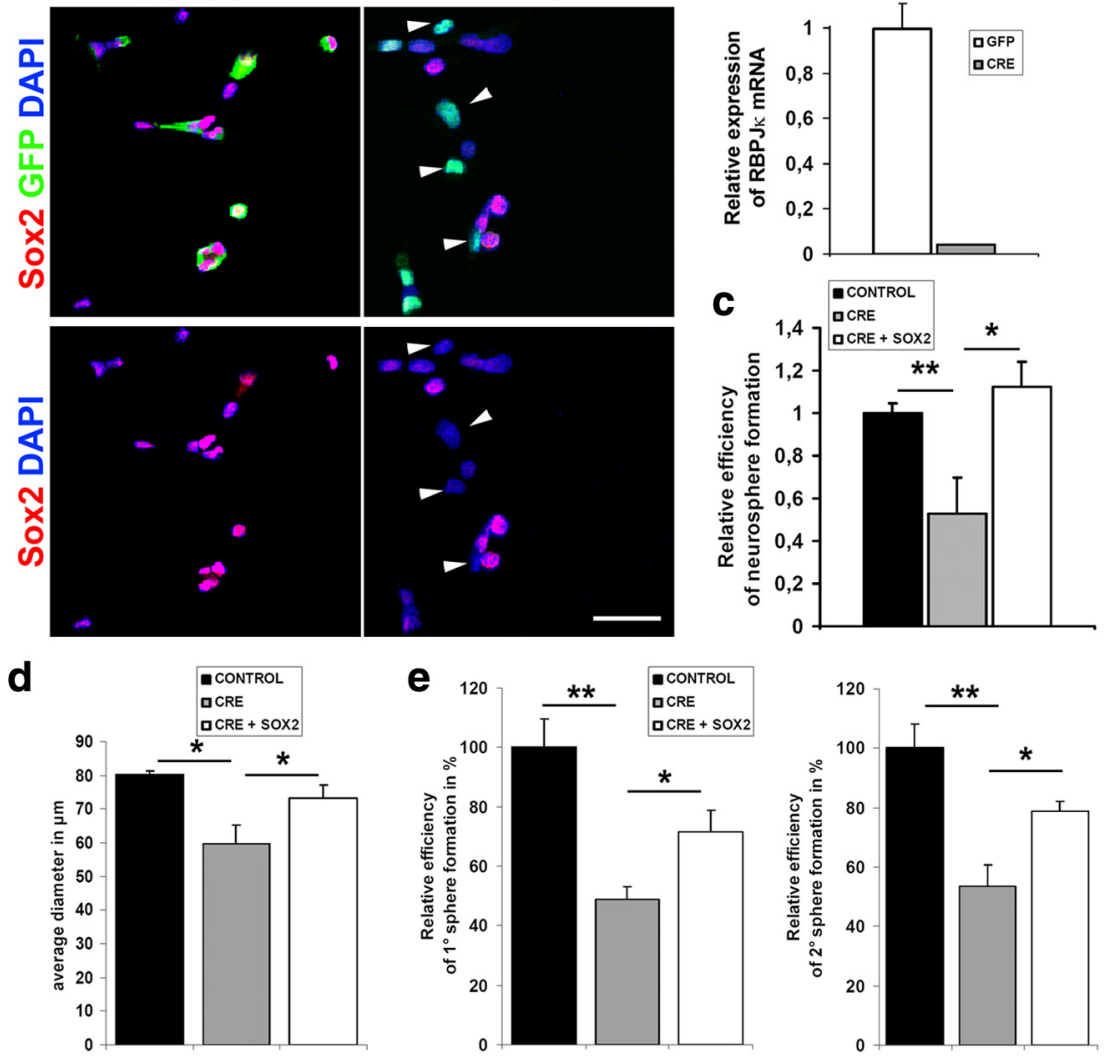

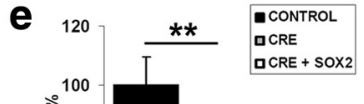
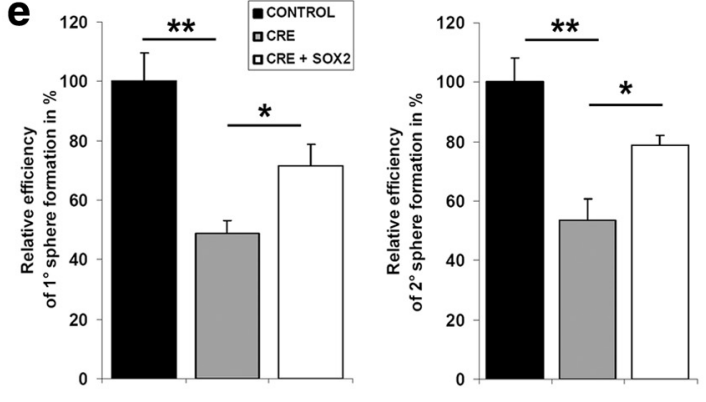

5 days
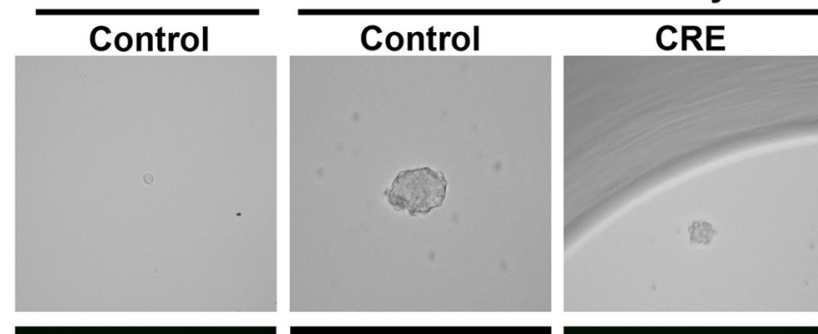

CRE + Sox 2
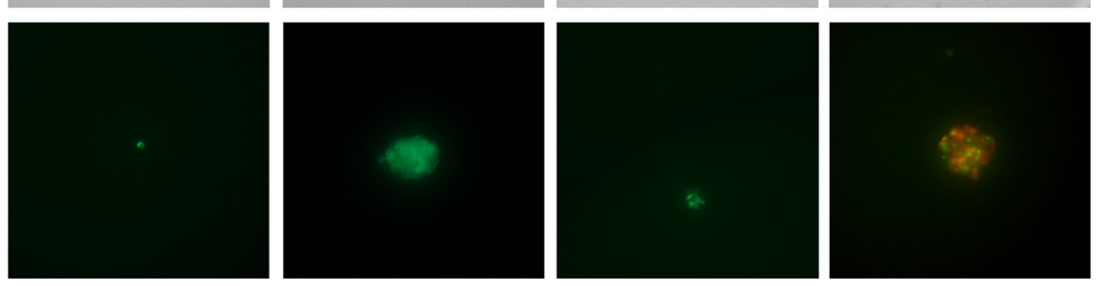

Figure 6. $\quad \boldsymbol{a}$, Immunocytochemical analysis of neurospheres derived from adult RBPJ $\kappa^{\text {loxp/loxp }}$ mice $48 \mathrm{~h}$ after transduction with the CAG-GFP (control) or the CAG-GFPnIsCRE (CRE-GFP) retrovirus (green). Cells were dissociated and fixed onto slides. Note that a number of CRE-GFP transduced cells are negative for Sox2 (red, arrowheads). $\boldsymbol{b}$, Quantitative PCR reveals significantly decreased $(p<0.001)$ expression of RBPJ $\kappa$ mRNA in CAG-GFPnIsCRE (CRE) transduced RBPJ $\kappa^{\text {loxp/loxp }}$ neurospheres. c $\boldsymbol{f}$, Neurosphere

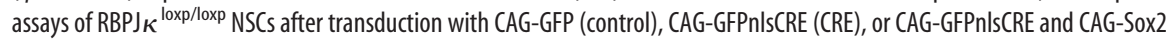

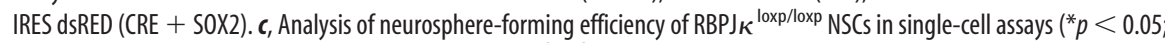
$\left.{ }^{* *} p<0.01\right) . d$, Analysis of neurosphere diameter of RBPJ $\kappa^{\text {loxp } / / 0 x p}$ NSCs $7 d$ after transduction $\left({ }^{*} p<0.05\right)$. e, Analysis of primary

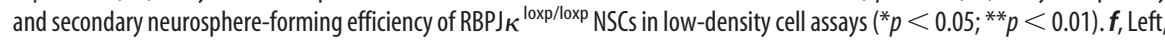
Representative image of a CAG-GFP transduced single cell $3 \mathrm{~h}$ after seeding into a miniwell. Right, Representative images of

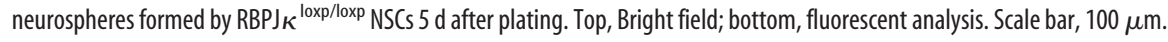

pressed in these cultures (supplemental Fig. 1, available at www.jneurosci.org as supplemental material). In addition, RTPCR analysis revealed expression of essential components of the canonical Notch-signaling cascade including Notch receptors 1-4 and RBPJ $\kappa$ and expression of the canonical Notch-signaling targets Hes 1 and Hes5 (Ohtsuka et al., 1999) (supplemental Fig. 1, available at 
a

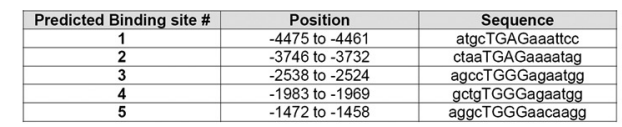

b

e

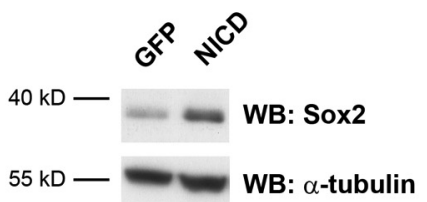

f

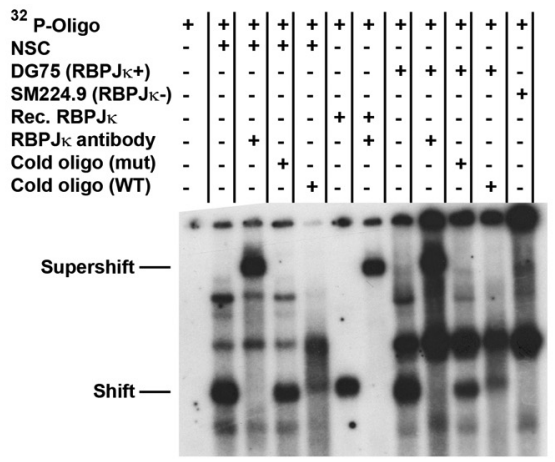

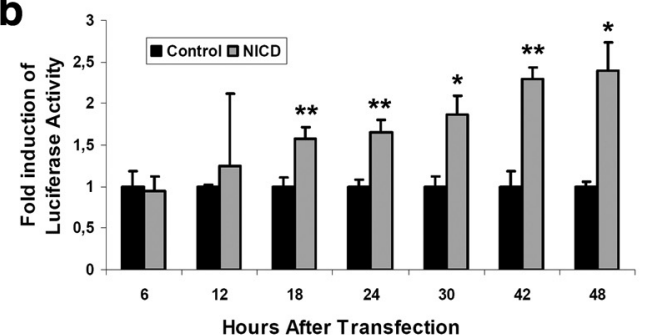

C
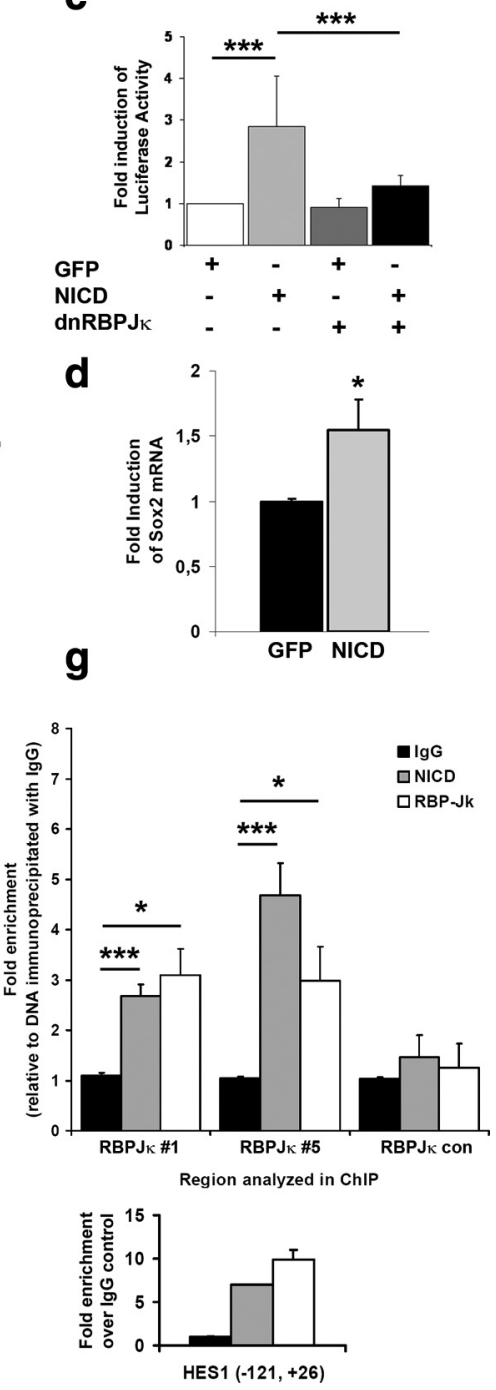

Figure 7. a, Summary of in silico analysis of the $5.5 \mathrm{~kb}$ mouse Sox2 promoter. The positions of the predicted RBPJ $\kappa$-binding sites are presented in relation to the transcriptional start site. $\boldsymbol{b}$, Reporter assays in HEK293 cells using the Sox2-luciferase show significant activation $18 \mathrm{~h}$ after transfection with NICD $\left({ }^{*} p<0.05 ;{ }^{* *} p<0.01\right)$. c, Reporter assays in adult hippocampal NSCS using a $5.5 \mathrm{~kb}$ Sox2-luciferase demonstrate that the Sox2 promoter is activated by Notch signaling. This activation was inhibited by expression of a dominant-negative form of RBPJ $\left.{ }^{*}{ }^{* * *} p<0.001\right)$. $\boldsymbol{d}$, Quantitative RT-PCR analysis of Sox2 mRNA expression in NSCs $6 \mathrm{~h}$ after transfection with an expression vector for NICD or a control expression vector encoding for GFP $\left({ }^{*} p<0.05\right)$. e, Western blot analysis of adult hippocampal NSCs after overexpression of NICD or GFP as control. Enhanced activation of Notch signaling by overexpression of NICD increases expression of Sox2. The loading control is $\alpha$-tubulin. $f$, EMSA shows binding of adult hippocampal NSC-derived RBPJ $\kappa$ to sequences (predicted binding site \#5) in the $5.5 \mathrm{~kb}$ Sox2 promoter. $\boldsymbol{g}$, ChIP analysis demonstrates that Sox2 is a direct target of Notch/RBPJ $\kappa$ signaling in adult NSCs. PCR primers were designed to surround the predicted

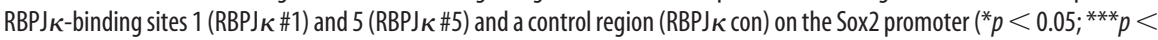
0.001). Bottom, ChIP analysis using PCR primers, which were designed to surround $\mathrm{RBPJ}_{\kappa}$ binding sites on the Hes 1 promoter, shows enrichment of Notch 1 and $\mathrm{RBPJ}_{\kappa}$ on the Hes 1 promoter in adult hippocampal NSCs.

www.jneurosci.

org as supplemental material). Finally, Western blot analysis revealed the presence of a $120 \mathrm{kDa}$ NICD fragment in nuclear extracts, which suggested that Notch signaling is active in adult hippocampal NSCs (supplemental Fig. 1, available at www.jneurosci. org as supplemental material). Enhanced activation of Notch signaling via electroporation of an NICD-expression construct resulted in an approximate threefold increase in Sox2-luciferase activity compared with overexpressed GFP, indicating that Notch signaling enhances Sox 2 promoter activity in adult hippocampal stem cells (Fig. $7 c)$. Coelectroporation of a dominant-negative RBPJ $\kappa$ expression construct (Kato et al., 1997) inhibited NICD-induced activation of the Sox 2 promoter, suggesting that NICDinduced activation of the Sox 2 promoter in NSCs is RBPJ $\kappa$ dependent (Fig. $7 c$ ). To examine whether enhanced Notch signaling promotes Sox 2 expression, adult hippocampal NSCs were electroporated with expression vectors for NICD or GFP as a control. Quantitative PCR analysis showed increased expression of Sox 2 already at $6 \mathrm{~h}$ after electroporation (Fig. $7 d$ ). Furthermore, immunoblots from cultures at $48 \mathrm{~h}$ after electroporation showed strongly increased endogenous Sox2 protein levels in cells overexpressing NICD (Fig. 7e). Together, these data indicate that Notch signaling indeed promotes Sox 2 expression in adult NSCs.

To further analyze potential RBPJ $\kappa$ binding sites in the $5.5 \mathrm{~kb}$ Sox 2 promoter, we conducted EMSAs with nuclear extracts from adult hippocampal stem cells. Oligonucleotides corresponding to the predicted RBPJ $\kappa$-binding site sequences from the $5.5 \mathrm{~kb}$ Sox 2 promoter were used in these assays. Repeated failure to radioactively label oligonucleotide for the predicted RBPJ $\kappa$-binding sites \#2 (-3746 to -3732$)$ and \#3 $(-2538$ to -2524$)$ precluded EMSA analysis of these sequences. Oligonucleotides encompassing the predicted binding sites \#1 ( -4475 to -4461$)$, \#4 $(-1983$ to -1969$)$, and $\# 5(-1472$ to -1458 ) were shifted on the gel after previous incubation with nuclear extracts from mouse stem/progenitor cells. Additional incubation with an antibody directed against RBPJ $\kappa$ resulted in a supershifted signal on the gel demonstrating that the observed shift was caused by binding of RBPJ $\kappa$. The same results were obtained with recombinant $\mathrm{RBPJ} \kappa$ protein and with nuclear extracts from RBPJ $\kappa$ overexpressing cells (DG75), whereas no shift was detected with nuclear extracts from an RBPJ $\kappa$ knock-out cell line (SM224.9) (Fig. 7f). These experiments showed that RBPJ $\kappa$ is present in the nucleus of adult hippocampal stem cells and that RBPJ $\kappa$ can bind to at least some of the predicted binding sites in the Sox 2 promoter.

Next, chromatin immunoprecipitation (ChIP) analysis was performed to directly investigate association of Notch-signaling components with the endogenous Sox 2 promoter in adult hippocampal NSCs and adult hippocampal neurospheres. Chromatin was precipitated with antibodies specific for RBPJ $\kappa$ and Notch1 and quantitatively analyzed by real-time PCR using primers flanking the predicted RBP $\kappa$ sites. Primers flanking previously confirmed RBPJ $\kappa$ sites in the Hes 1 promoter served as a positive control. ChIP using unspecific IgG and PCR using prim- 
ers against an unrelated sequence were used as controls. Lack of suitable antibodies against Notch 2-4 precluded ChIP analysis of the Sox 2 promoter for these proteins. As expected, enrichment of RBPJ $\kappa$ and Notch1 was observed on RBPJ $\kappa$ sites in the Hes 1 promoter. Importantly, enrichment of RBPJ $\kappa$ and Notch1 was found on the predicted RBPJ $\kappa$ sites \#1 and \#5 within the endogenous $5.5 \mathrm{~kb}$ Sox 2 promoter, demonstrating that Sox 2 is a direct target of Notch/ RBPJ $\kappa$ signaling in adult NSCs (Fig. $7 g$ ). Because only activated Notch translocates to the nucleus to interact with the transcriptional regulator $\mathrm{RBPJ} \kappa$ to induce the target gene expression, the association of Notch1 and RBPJ $\kappa$ on the Sox 2 promoter indicates that active Notch/RBPJ $\kappa$ signaling directly targets the Sox 2 promoter in adult hippocampal NSCs.

Having identified the essential stem cell maintenance gene as a Notch/RBPJ $\kappa$ signaling target and given the observation that Sox2 expression is decreased after inactivation of RBPJ $\kappa$, we asked the question whether Sox 2 expression can compensate for the stem cell maintenance/self-renewal defect of RBPJ $\kappa$-deficient NSCs. To this end, RBPJ $\kappa^{\text {loxp/loxp }}$ neurospheres were transduced with CRE-GFP in combination with a retrovirus encoding for Sox 2 and red fluorescent protein and subjected to the single-cell neurosphere assay $48 \mathrm{~h}$ later. Independent experiments showed that Sox 2 expression in nonrecombined NSCs does not enhance the efficiency of neurosphere formation (supplemental Fig. 1, available at www.jneurosci.org as supplemental material). Strikingly, Sox2 rescued the neurosphere-forming defect of RBPJ $\kappa$-deficient NSCs in single-cell assays (Fig. $6 c, d, f$ ) and greatly enhanced the ability of RBPJ $\kappa$-deficient NSCs to generate primary and secondary neurospheres in low cell density neurosphere assays (Fig. 6e). These results indicate that Sox2 can, at least in part, functionally compensate for loss of RBPJ $\kappa$ signaling with regard to stem cell self-renewal and strongly suggest that a Notch/RBPJ /Sox2 pathway is contributing to adult NSC maintenance.

\section{Discussion}

The balance of NSC maintenance and neurogenesis is essential to ensure the generation of new hippocampal granule neurons throughout lifetime at a functionally relevant rate. Our study demonstrates that RBPJ $\kappa$ is an essential component of the regulatory network controlling this balance, as inactivation of RBPJ $\kappa$ in NSCs results in depletion of the stem cell compartment and a transient burst in proliferation and the production of new neurons. The long-term consequence of impaired stem cell maintenance after loss of RBPJ $\kappa$ is an almost complete loss of hippocampal neurogenesis.

$\mathrm{RBPJ} \kappa$ is the central transcriptional downstream effector in canonical Notch signaling. We observed that Notch/RBPJ $\kappa 32$ signaling is active in NSCs in vivo and in vitro, which indicates that the phenotype of RBPJ $\kappa$-cKO is the consequence of loss of canonical Notch signaling. This argument is supported by the findings that loss of Notch1 receptor in adult NSCs also results in loss of the radial glia-like stem cell population (Ables et al., 2010) and increased neuronal differentiation of stem cells (Breunig et al., 2007). It is, however, important to note that inactivation of RBPJ $\kappa$ and of Notch 1 does not produce completely similar phenotypes. Loss of Notch1 in stem cells of the early postnatal hippocampus does not lead to a transient increase in stem cell proliferation but, rather, promotes cell cycle exit (Breunig et al., 2007). Moreover, overexpression of activated Notch in stem cells of the early postnatal hippocampus strongly enhances proliferation (Breunig et al., 2007). It is possible that Notch/RBPJ $\kappa 32$ signaling has distinct functions during the early postnatal period and during adulthood. It is, however, more likely that the phenotypic differences are caused by the fact that Notch signaling was perturbed at different levels. We and others have found that other Notch receptors are expressed in NSCs (supplemental Fig. 1, available at www.jneurosci.org as supplemental material) and the hippocampal neurogenic niche (Breunig et al., 2007), raising the possibility that signaling of other Notch receptors through RBPJ $\kappa$ in the Notch 1 mutants may be responsible for the phenotypic differences. It has also been demonstrated that RBPJ $\kappa$ independent Notch signaling promotes stem cell proliferation in the adult CNS (Androutsellis-Theotokis et al., 2006). Because $\mathrm{RBPJ} \kappa$-independent pathways are left intact in the $\mathrm{RBPJ} \kappa$-cKO, the phenotypic differences could also be the result of differences in the activity of noncanonical Notch signaling in NSCs.

Recent studies revealed considerable heterogeneity among NSCs from distinct neurogenic regions with regard to their differentiation pattern (Hack et al., 2005; Merkle et al., 2007; Brill et al., 2009) and their proliferative/self-renewal behavior (Seaberg and van der Kooy, 2002; Bull and Bartlett, 2005). In addition, a number of signaling pathways appear to have region-specific functions on adult NSC proliferation and differentiation (Kuhn et al., 1997; Lie et al., 2005; Adachi et al., 2007). Imayoshi et al. (2010) recently reported that inactivation of RBPJ $\kappa$ in stem cells of the adult subventricular zone results in a neurogenesis phenotype, which is highly similar to the hippocampal neurogenesis phenotype observed in this study. Together, these studies provide strong evidence for the notion that the mechanisms of stem cell maintenance are shared between the principal adult neurogenic niches. In contrast to the study of Imayoshi et al. (2010), RBPJ $\kappa$ conditional knock-out mice in this study also carried a R26::EYFP reporter. Analysis of the YFP-positive and -negative populations surprisingly revealed that proliferation and neurogenesis from YFP-negative cells was substantially altered in RBPJ $\kappa$-cKO mice and that YFP-negative stem cells were not able to sustain significant levels of neurogenesis. Several studies have indicated that stem cells themselves create a neurogenic microenvironment that provides signals for proliferation and differentiation (Lim and Alvarez-Buylla, 1999; Lim et al., 2000; Song et al., 2002; Lie et al., 2005; Favaro et al., 2009). Hence, we propose that the loss of RBPJ $\kappa$ and the reduction of stem cells alters signaling in the neurogenic microenvironment, which in turn resulted in global dysregulation of neurogenesis from the remaining nonrecombined stem cells. It will be interesting to determine in the future whether RBPJ $\kappa 32$ signaling controls the neurogenic microenvironment through the transcriptional regulation of, for example, secreted and cell-surface-bound signaling molecules.

Single-cell neurosphere assays demonstrated that RBPJ $\kappa 32$ signaling controls stem cell maintenance, at least in part, through cell-autonomous mechanisms. Recent work by Favaro et al. (2009) has demonstrated that the transcription factor Sox2 is essential for adult hippocampal NSC maintenance. We found that activation of the Notch-signaling pathway, which leads to the transcriptional activation of RBPJ $\kappa$-targets, enhances the activity of the Sox 2 promoter and the expression of Sox 2 in adult hippocampal NSCs. In addition, we show that the Sox 2 promoter contains multiple RBPJ $\kappa$-binding sites and that RBPJ $\kappa$ and activated Notch are enriched on the Sox 2 promoter in adult hippocampal NSCs. Thus, we identify Sox 2 as a direct target of Notch/ RBPJ $\kappa 32$ signaling in adult hippocampal NSCs. Importantly, Sox 2 overexpression is sufficient to rescue the self-renewal defect of RBPJ $\kappa$-deficient adult NSCs in culture, indicating that the Notch/RBPJ $\kappa /$ Sox 2 pathway is functionally relevant for NSC 
maintenance. Together with the finding that Sox 2 inhibits Wnt/ $\beta$-catenin-induced fate determination (Lie et al. 2005) and expression of the neuronal fate determinant NeuroD (Kuwabara et al., 2009), our data suggest a model in which the activity of the Notch/RBPJ $\kappa /$ Sox 2 pathway and the activity of the Wnt/ $\beta$-catenin/NeuroD pathway are key regulators to control the balance between stem cell maintenance and neuronal fate determination in the adult hippocampal neurogenic niche.

Notch 1 was identified as a direct transcriptional target of Sox2 in retinal progenitor cells (Taranova et al., 2006), raising the possibility of a positive Notch-Sox2-Notch feedback loop. Our ChIP analysis using chromatin from adult NSCs revealed no significant enrichment of Sox 2 on the Notch 1 promoter. Hence, we have no evidence for a Notch-Sox2-Notch feedback loop in adult NSCs, which is in line with the finding that the expression of Notch1, RBPJk, and Notch targets such as Hes5 is unaltered in Sox2deficient adult NSCs (Favaro et al., 2009).

Notch signaling interacts with a number of other pathways to control stem cell maintenance in the hematopoietic system (Duncan et al., 2005), the embryonic nervous system (Takizawa et al., 2003; Shimizu et al., 2008), and the adult subventricular zone (Andreu-Agullo et al., 2009). In addition, it has been found that Sox2 expression in the developing nervous system is influenced by sonic hedgehog (Takanaga et al., 2009) and fibroblast growth factor signaling (Takemoto et al., 2006). We therefore consider it likely that Notch/RBPJ $\kappa$ signaling controls stem cell maintenance in the adult hippocampus in cooperation with additional signals. In preliminary studies, we have found that modulation of the PI3kinase pathway and of the $\mathrm{Wnt} / \beta$-catenin pathway potentiate Notch-induced Sox 2 promoter activity in adult NSCs (O. Ehm, T. J. Schwarz, and A. Khan, unpublished results), which indeed suggests that multiple pathways converge onto Sox 2 and regulate NSC maintenance in the hippocampus. Activity of such interacting pathways in the absence of Notch/ RBPJ $\kappa$ signaling may be sufficient to sustain Sox 2 expression for a short period of time, which could explain the observation that a fraction of the YFP reporter-positive cells in RBPJ $\kappa$-cKO mice showed residual Sox 2 protein expression.

RBPJ $\kappa$-cKO and Sox 2 -conditional mouse mutants both show loss of hippocampal NSCs and loss of neurogenesis. Sox $2 \mathrm{mu}-$ tants, however, display proliferation and neurogenesis defects almost immediately after recombination, which is different from the transient increase in proliferation and neurogenesis in $\mathrm{RBPJ} \kappa$-cKO. It is likely that these phenotypic differences are attributable to the fact that $\mathrm{RBPJ} \kappa$-dependent signaling regulates NSC behavior not only through Sox 2 but also through other downstream targets. This idea is supported by the observations that the Notch targets Hes1 and Hes5 are expressed in adult neurogenic niches (Stump et al., 2002; Crews et al., 2008) and that stem cells in the adult hippocampus (Fig. 1) and the adult subventricular zone (Imayoshi et al., 2010) show robust activity of the Hes 5 promoter. In addition, we demonstrate that adult NSCs express Hes1 and Hes5 (supplemental Fig. 1, available at www.jneurosci.org as supplemental material), that overexpression of activated Notch increases Hes 1 mRNA expression, and that activated Notch is enriched on the Hes1 promoter (Fig. 7f). The fact that Hes1 is essential for reversible quiescence in primary cells and tumor cells in vitro (Sang et al., 2008 ) and the fact that inactivation of RBPJ $\kappa$ leads to loss of the quiescent radial glia-like stem cell population and a transient increase in proliferation (this study) raise the intriguing possibility that Notch/RBPJ $\kappa$ regulate quiescence of radial glia-like stem cells through the control of Hes gene expression.
We expect that the characterization of the transcriptional targets of RBPJ $\kappa$ signaling in NSCs will provide a deeper insight into the complex regulatory mechanisms underlying stem cell behavior in the adult hippocampus.

The strongly reduced generation of new dentate granule neurons in the aged hippocampus is thought to contribute to agedependent hippocampal dysfunction. In vitro assays for NSC frequency (Walker et al., 2008), histological studies in primates (Aizawa et al., 2010), and magnetic resonance spectroscopy studies in humans (Manganas et al., 2007) indicated that the stem cell pool in the aged dentate gyrus is reduced and that incomplete stem cell maintenance may play a role in age-associated reduction of hippocampal neurogenesis. Interestingly, analysis of A53T $\alpha$-synuclein transgenic mice, a model for age-dependent neurodegeneration, revealed a pronounced decrease in hippocampal neurogenesis that is paralleled by a significant decrease in Notch1 expression (Crews et al., 2008). Together with our finding that $\mathrm{RBPJ} \kappa$-dependent signaling is essential for NSC maintenance in the dentate gyrus during adulthood, these observations raise the intriguing possibility that perturbations of Notch/RBPJ $\kappa$ signaling contribute to stem cell loss, decreased neurogenesis, and impaired hippocampal function during aging and that pharmacological stimulation of the Notch/RBPJ $\kappa$ pathway may potentially prevent age-associated loss of NSCs and its consequences for hippocampal function.

\section{References}

Ables JL, Decarolis NA, Johnson MA, Rivera PD, Gao Z, Cooper DC, Radtke F, Hsieh J, Eisch AJ (2010) Notch1 is required for maintenance of the reservoir of adult hippocampal stem cells. J Neurosci 30:10484-10492.

Adachi K, Mirzadeh Z, Sakaguchi M, Yamashita T, Nikolcheva T, Gotoh Y, Peltz G, Gong L, Kawase T, Alvarez-Buylla A, Okano H, Sawamoto K (2007) Beta-catenin signaling promotes proliferation of progenitor cells in the adult mouse subventricular zone. Stem Cells 25:2827-2836.

Aizawa K, Ageyama N, Terao K, Hisatsune T (2010) Primate-specific alterations in neural stem/progenitor cells in the aged hippocampus. Neurobiol Aging, in press.

Andreu-Agullo C, Morante-Redolat JM, Delgado AC, Farinas I (2009) Vascular niche factor PEDF modulates Notch-dependent stemness in the adult subependymal zone. Nat Neurosci 12:1514-1523.

Androutsellis-Theotokis A, Leker RR, Soldner F, Hoeppner DJ, Ravin R, Poser SW, Rueger MA, Bae SK, Kittappa R, McKay RD (2006) Notch signalling regulates stem cell numbers in vitro and in vivo. Nature 442:823-826.

Baron M (2003) An overview of the Notch signalling pathway. Semin Cell Dev Biol 14:113-119.

Basak O, Taylor V (2007) Identification of self-replicating multipotent progenitors in the embryonic nervous system by high Notch activity and Hes5 expression. Eur J Neurosci 25:1006-1022.

Ben-Bassat H, Goldblum N, Mitrani S, Goldblum T, Yoffey JM, Cohen MM, Bentwich Z, Ramot B, Klein E, Klein G (1977) Establishment in continuous culture of a new type of lymphocyte from a "Burkitt like" malignant lymphoma (line D.G.-75). Int J Cancer 19:27-33.

Bergami M, Rimondini R, Santi S, Blum R, Gotz M, Canossa M (2008) Deletion of TrkB in adult progenitors alters newborn neuron integration into hippocampal circuits and increases anxiety-like behavior. Proc Natl Acad Sci U S A 105:15570-15575.

Blanpain C, Lowry WE, Pasolli HA, Fuchs E (2006) Canonical notch signaling functions as a commitment switch in the epidermal lineage. Genes Dev 20:3022-3035.

Breunig JJ, Silbereis J, Vaccarino FM, Sestan N, Rakic P (2007) Notch regulates cell fate and dendrite morphology of newborn neurons in the postnatal dentate gyrus. Proc Natl Acad Sci U S A 104:20558-20563.

Brill MS, Ninkovic J, Winpenny E, Hodge RD, Ozen I, Yang R, Lepier A, Gascon S, Erdelyi F, Szabo G, Parras C, Guillemot F, Frotscher M, Berninger B, Hevner RF, Raineteau O, Gotz M (2009) Adult generation of glutamatergic olfactory bulb interneurons. Nat Neurosci 12:1524-1533. 
Bull ND, Bartlett PF (2005) The adult mouse hippocampal progenitor is neurogenic but not a stem cell. J Neurosci 25:10815-10821.

Clelland CD, Choi M, Romberg C, Clemenson GD Jr, Fragniere A, Tyers P, Jessberger S, Saksida LM, Barker RA, Gage FH, Bussey TJ (2009) A functional role for adult hippocampal neurogenesis in spatial pattern separation. Science 325:210-213.

Crews L, Mizuno H, Desplats P, Rockenstein E, Adame A, Patrick C, Winner B, Winkler J, Masliah E (2008) $\alpha$-synuclein alters Notch-1 expression and neurogenesis in mouse embryonic stem cells and in the hippocampus of transgenic mice. J Neurosci 28:4250-4260.

Deng W, Saxe MD, Gallina IS, Gage FH (2009) Adult-born hippocampal dentate granule cells undergoing maturation modulate learning and memory in the brain. J Neurosci 29:13532-13542.

Drapeau E, Mayo W, Aurousseau C, Le Moal M, Piazza PV, Abrous DN (2003) Spatial memory performances of aged rats in the water maze predict levels of hippocampal neurogenesis. Proc Natl Acad Sci U S A 100:14385-14390.

Duncan AW, Rattis FM, DiMascio LN, Congdon KL, Pazianos G, Zhao C, Yoon K, Cook JM, Willert K, Gaiano N, Reya T (2005) Integration of Notch and Wnt signaling in hematopoietic stem cell maintenance. Nat Immunol 6:314-322.

Favaro R, Valotta M, Ferri AL, Latorre E, Mariani J, Giachino C, Lancini C, Tosetti V, Ottolenghi S, Taylor V, Nicolis SK (2009) Hippocampal development and neural stem cell maintenance require Sox2-dependent regulation of Shh. Nat Neurosci 12:1248-1256.

Gao Z, Ure K, Ables JL, Lagace DC, Nave KA, Goebbels S, Eisch AJ, Hsieh J (2009) Neurodl is essential for the survival and maturation of adultborn neurons. Nat Neurosci.

Hack MA, Saghatelyan A, de Chevigny A, Pfeifer A, Ashery-Padan R, Lledo PM, Gotz M (2005) Neuronal fate determinants of adult olfactory bulb neurogenesis. Nat Neurosci 8:865-872.

Han H, Tanigaki K, Yamamoto N, Kuroda K, Yoshimoto M, Nakahata T, Ikuta K, Honjo T (2002) Inducible gene knockout of transcription factor recombination signal binding protein-J reveals its essential role in $\mathrm{T}$ versus B lineage decision. Int Immunol 14:637-645.

Haslinger A, Schwarz TJ, Covic M, Chichung Lie D (2009) Expression of Sox11 in adult neurogenic niches suggests a stage-specific role in adult neurogenesis. Eur J Neurosci 29:2103-2114.

Hitoshi S, Alexson T, Tropepe V, Donoviel D, Elia AJ, Nye JS, Conlon RA, Mak TW, Bernstein A, van der Kooy D (2002) Notch pathway molecules are essential for the maintenance, but not the generation, of mammalian neural stem cells. Genes Dev 16:846-858.

Imayoshi I, Sakamoto M, Ohtsuka T, Takao K, Miyakawa T, Yamaguchi M, Mori K, Ikeda T, Itohara S, Kageyama R (2008) Roles of continuous neurogenesis in the structural and functional integrity of the adult forebrain. Nat Neurosci 11:1153-1161.

Imayoshi I, Sakamoto M, Yamaguchi M, Mori K, Kageyama R (2010) Essential roles of notch signaling in maintenance of neural stem cells in developing and adult brains. J Neurosci 30:3489-3498.

Jagasia R, Steib K, Englberger E, Herold S, Faus-Kessler T, Saxe M, Gage FH, Song H, Lie DC (2009) GABA-cAMP response element-binding protein signaling regulates maturation and survival of newly generated neurons in the adult hippocampus. J Neurosci 29:7966-7977.

Jakubs K, Nanobashvili A, Bonde S, Ekdahl CT, Kokaia Z, Kokaia M, Lindvall O (2006) Environment matters: synaptic properties of neurons born in the epileptic adult brain develop to reduce excitability. Neuron 52:1047-1059.

Jessberger S, Romer B, Babu H, Kempermann G (2005) Seizures induce proliferation and dispersion of doublecortin-positive hippocampal progenitor cells. Exp Neurol 196:342-351.

Jessberger S, Clark RE, Broadbent NJ, Clemenson GD Jr, Consiglio A, Lie DC, Squire LR, Gage FH (2009) Dentate gyrus-specific knockdown of adult neurogenesis impairs spatial and object recognition memory in adult rats. Learn Mem 16:147-154.

Kaspar BK, Vissel B, Bengoechea T, Crone S, Randolph-Moore L, Muller R, Brandon EP, Schaffer D, Verma IM, Lee KF, Heinemann SF, Gage FH (2002) Adeno-associated virus effectively mediates conditional gene modification in the brain. Proc Natl Acad Sci U S A 99:2320-2325.

Kato H, Taniguchi Y, Kurooka H, Minoguchi S, Sakai T, Nomura-Okazaki S, Tamura K, Honjo T (1997) Involvement of RBP-J in biological functions of mouse Notch1 and its derivatives. Development 124:4133-4141.
Kee N, Teixeira CM, Wang AH, Frankland PW (2007) Preferential incorporation of adult-generated granule cells into spatial memory networks in the dentate gyrus. Nat Neurosci 10:355-362.

Kempermann G, Jessberger S, Steiner B, Kronenberg G (2004) Milestones of neuronal development in the adult hippocampus. Trends Neurosci 27:447-452.

Kuhn HG, Dickinson-Anson H, Gage FH (1996) Neurogenesis in the dentate gyrus of the adult rat: age-related decrease of neuronal progenitor proliferation. J Neurosci 16:2027-2033.

Kuhn HG, Winkler J, Kempermann G, Thal LJ, Gage FH (1997) Epidermal growth factor and fibroblast growth factor-2 have different effects on neural progenitors in the adult rat brain. J Neurosci 17:5820-5829.

Kuwabara T, Hsieh J, Muotri A, Yeo G, Warashina M, Lie DC, Moore L, Nakashima K, Asashima M, Gage FH (2009) Wnt-mediated activation of NeuroD1 and retro-elements during adult neurogenesis. Nat Neurosci 12:1097-1105.

Lengler J, Bittner T, Munster D, Gawad Ael D, Graw J (2005) Agonistic and antagonistic action of AP2, Msx2, Pax6, Prox1 AND Six3 in the regulation of Sox2 expression. Ophthalmic Res 37:301-309.

Lie DC, Colamarino SA, Song HJ, Desire L, Mira H, Consiglio A, Lein ES, Jessberger S, Lansford H, Dearie AR, Gage FH (2005) Wnt signalling regulates adult hippocampal neurogenesis. Nature 437:1370-1375.

Lim DA, Alvarez-Buylla A (1999) Interaction between astrocytes and adult subventricular zone precursors stimulates neurogenesis. Proc Natl Acad Sci U S A 96:7526-7531.

Lim DA, Tramontin AD, Trevejo JM, Herrera DG, Garcia-Verdugo JM, Alvarez-Buylla A (2000) Noggin antagonizes BMP signaling to create a niche for adult neurogenesis. Neuron 28:713-726.

Maier S, Santak M, Mantik A, Grabusic K, Kremmer E, Hammerschmidt W, Kempkes B (2005) A somatic knockout of CBF1 in a human B-cell line reveals that induction of CD21 and CCR7 by EBNA-2 is strictly CBF1 dependent and that downregulation of immunoglobulin $\mathrm{M}$ is partially CBF1 independent. J Virol 79:8784-8792.

Manganas LN, Zhang X, Li Y, Hazel RD, Smith SD, Wagshul ME, Henn F, Benveniste H, Djuric PM, Enikolopov G, Maletic-Savatic M (2007) Magnetic resonance spectroscopy identifies neural progenitor cells in the live human brain. Science 318:980-985.

Merkle FT, Mirzadeh Z, Alvarez-Buylla A (2007) Mosaic organization of neural stem cells in the adult brain. Science 317:381-384.

Mizutani K, Yoon K, Dang L, Tokunaga A, Gaiano N (2007) Differential Notch signalling distinguishes neural stem cells from intermediate progenitors. Nature 449:351-355.

Ohtsuka T, Ishibashi M, Gradwohl G, Nakanishi S, Guillemot F, Kageyama R (1999) Hes1 and Hes5 as notch effectors in mammalian neuronal differentiation. EMBO J 18:2196-2207.

Parent JM, Elliott RC, Pleasure SJ, Barbaro NM, Lowenstein DH (2006) Aberrant seizure-induced neurogenesis in experimental temporal lobe epilepsy. Ann Neurol 59:81-91.

Ray J, Gage FH (2006) Differential properties of adult rat and mouse brainderived neural stem/progenitor cells. Mol Cell Neurosci 31:560-573.

Revest JM, Dupret D, Koehl M, Funk-Reiter C, Grosjean N, Piazza PV, Abrous DN (2009) Adult hippocampal neurogenesis is involved in anxiety-related behaviors. Mol Psychiatry.

Sang L, Coller HA, Roberts JM (2008) Control of the reversibility of cellular quiescence by the transcriptional repressor HES1. Science 321:1095-1100.

Seaberg RM, van der Kooy D (2002) Adult rodent neurogenic regions: the ventricular subependyma contains neural stem cells, but the dentate gyrus contains restricted progenitors. J Neurosci 22:1784-1793.

Shimizu T, Kagawa T, Inoue T, Nonaka A, Takada S, Aburatani H, Taga T (2008) Stabilized beta-catenin functions through TCF/LEF proteins and the Notch/RBP-Jkappa complex to promote proliferation and suppress differentiation of neural precursor cells. Mol Cell Biol 28:7427-7441.

Slezak M, Goritz C, Niemiec A, Frisen J, Chambon P, Metzger D, Pfrieger FW (2007) Transgenic mice for conditional gene manipulation in astroglial cells. Glia 55:1565-1576.

Song H, Stevens CF, Gage FH (2002) Astroglia induce neurogenesis from adult neural stem cells. Nature 417:39-44.

Song X, Call GB, Kirilly D, Xie T (2007) Notch signaling controls germline stem cell niche formation in the Drosophila ovary. Development 134:1071-1080.

Srinivas S, Watanabe T, Lin CS, William CM, Tanabe Y, Jessell TM, 
Costantini F (2001) Cre reporter strains produced by targeted insertion of EYFP and ECFP into the ROSA26 locus. BMC Dev Biol 1:4.

Stump G, Durrer A, Klein AL, LutolfS, Suter U, Taylor V (2002) Notch1 and its ligands Delta-like and Jagged are expressed and active in distinct cell populations in the postnatal mouse brain. Mech Dev 114:153-159.

Suh H, Consiglio A, Ray J, Sawai T, D’Amour KA, Gage FH (2007) In vivo fate analysis reveals the multipotent and self-renewal capacities of Sox $2(+)$ neural stem cells in the adult hippocampus. Cell Stem Cell 1:515-528.

Takanaga H, Tsuchida-Straeten N, Nishide K, Watanabe A, Aburatani H, Kondo T (2009) Gli2 is a novel regulator of sox2 expression in telencephalic neuroepithelial cells. Stem Cells 27:165-174.

Takemoto T, Uchikawa M, Kamachi Y, Kondoh H (2006) Convergence of Wnt and FGF signals in the genesis of posterior neural plate through activation of the Sox 2 enhancer N-1. Development 133:297-306.

Takizawa T, Ochiai W, Nakashima K, Taga T (2003) Enhanced gene activation by Notch and BMP signaling cross-talk. Nucleic Acids Res 31: 5723-5731.
Taranova OV, Maness ST, Fagan BM, Wu Y, Surzenko N, Hutton SR, Pevny LH (2006) SOX2 is a dose-dependent regulator of retinal neural progenitor competence. Genes Dev 20:1187-1202.

Tashiro A, Zhao C, Gage FH (2006) Retrovirus-mediated single-cell gene knockout technique in adult newborn neurons in vivo. Nat Protoc 1:3049-3055.

Walker TL, White A, Black DM, Wallace RH, Sah P, Bartlett PF (2008) Latent stem and progenitor cells in the hippocampus are activated by neural excitation. J Neurosci 28:5240-5247.

Yamamoto N, Tanigaki K, Han H, Hiai H, Honjo T (2003) Notch/RBP-J signaling regulates epidermis/hair fate determination of hair follicular stem cells. Curr Biol 13:333-338.

Zappone MV, Galli R, Catena R, Meani N, De Biasi S, Mattei E, Tiveron C, Vescovi AL, Lovell-Badge R, Ottolenghi S, Nicolis SK (2000) Sox2 regulatory sequences direct expression of a (beta)-geo transgene to telencephalic neural stem cells and precursors of the mouse embryo, revealing regionalization of gene expression in CNS stem cells. Development 127: 2367-2382. 